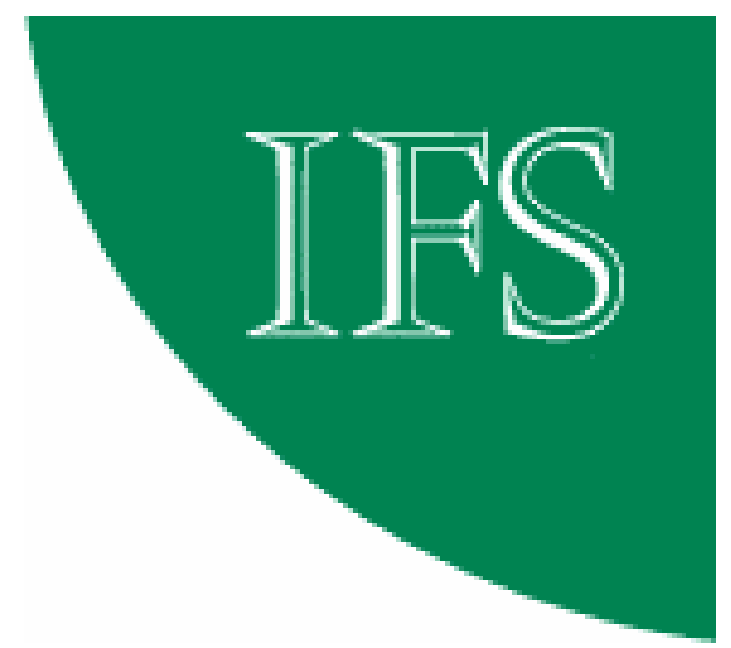

\title{
DisSECTING DIVIDEND DECISIONS: SOME ClUES ABOUT THE EFFECTS OF DIVIDEND TAXATION FROM RECENT UK REFORMS
}

\author{
Stephen R. Bond \\ Michael P. Devereux \\ Alexander Klemm
}




\title{
Dissecting Dividend Decisions:
}

\section{Some Clues About the Effects of Dividend Taxation from Recent UK Reforms}

\author{
Stephen R Bond \\ Institute for Fiscal Studies and Nuffield College, Oxford \\ Michael P Devereux \\ University of Warwick and Institute for Fiscal Studies \\ Alexander Klemm \\ Institute for Fiscal Studies and University College London
}

June 27, 2005

\begin{abstract}
We present empirical evidence which suggests that a big increase in dividend taxation for UK pension funds in July 1997 affected the form in which some UK companies chose to make dividend payments, but otherwise had limited effects on both the level of dividend payments and the level of investment. These findings are consistent with a version of the 'new view' of dividend taxation. We also identify a group of firms whose dividend choices are difficult to reconcile with (stock market) value maximisation.

Acknowledgement: This paper is part of the research of the Large Business Tax Programme at the Institute for Fiscal Studies, supported by the Hundred Group, the Inland Revenue, and the ESRC Centre for Public Policy. We thank Alan Auerbach, Tim Besley, Roger Gordon, Jim Hines, Stephen Matthews, Jim Poterba, Joel Slemrod, David Ulph and participants in seminars at the ESRC Public Economics Working Group, IFS, IMF, the Inland Revenue, University of Manchester, University of Michigan, University College London and University of Warwick for helpful comments.
\end{abstract}


Non-technical Summary

In this paper we use data for a sample of 696 quoted non-financial UK companies to investigate empirically whether any changes in dividend or investment behaviour can be detected following the abolition of repayable dividend tax credits for UK pension providers in July 1997.

This tax reform was intended to have a significant impact on the dividend decisions and investment spending of UK companies. More specifically, it was intended to reduce pressure from pension funds for UK firms to pay out a high share of their profits in the form of dividends, and thereby to allow firms to increase their investment spending.

The tax treatment of dividends paid to UK pension funds before 1997 was certainly not neutral, and was unusual in that for these institutional investors there was a more favorable tax treatment of dividend income than capital gains. To what extent this affected company dividend decisions is far from clear, however, for two quite different reasons.

First, given that some other investors (e.g. higher rate taxpayers) had a more favorable tax treatment of capital gains than dividends, while others (e.g. basic rate taxpayers and some foreign institutions) had no tax preference, the influence that UK pension funds could exercise over company dividend policies is uncertain.

Second, even if UK pension funds were influential, it is unclear whether their tax preference for dividend income would affect dividend payments. That is, if other non-tax costs associated with issuing equity are sufficiently important that retained profits were still the cheapest source of finance for UK companies in the period before 1997, it is entirely possible that the abolition of repayable dividend tax credits for UK pension funds would have had no effect on the level of dividends. This is the prediction of a version of the so-called 'new view' of dividend taxation, which in essence says that if issuing equity is a more expensive source of finance than retaining profits, then dividends should anyhow be minimised, and an increase in the tax cost of paying dividends has no impact.

The link from dividend taxation to investment spending is still more tenuous. The majority of company investment is financed from retained profits. For such investment, the taxation of dividends reduces the cost to shareholders of financing the investment (i.e. foregone current dividends) as well as the eventual return on the investment (i.e. higher future dividends). At least for investment financed from retained profits, the 'new view' predicts that the level of dividend taxation has no effect on the cost of capital, and therefore has little or no impact on firms' investment decisions.

We exploit detailed provisions of UK dividend taxation in the 1990s to identify a group of firms whose behaviour before July 1997 was consistent with the tax preference of UK pension funds. At that time, UK companies with foreign profits could choose to pay a form of dividends called Foreign Income Dividends (FIDs). For many firms, paying FIDs rather than ordinary dividends would have been tax efficient for most types of shareholders. But before July 1997, paying FIDs rather than ordinary dividends was not tax efficient for UK pension funds, because there were no tax credits on FIDs that pension providers could reclaim. 
We document that the payment of FIDs was comparatively rare before the abolition of repayable tax credits on ordinary dividends. This reform aligned the treatment of ordinary dividends received by pension funds with the treatment of FIDs, so that if the firm could make a tax saving by distributing profits in the form of FIDs, this choice became tax efficient after July 1997 also from the perspective of UK pension funds, as well as other types of shareholders. We show that the use of FIDs became much more significant from July 1997 until the abolition of FIDs in April 1999, with both the number of firms paying FIDs and the share of total dividends paid in the form of FIDs increasing threefold compared to the period before July 1997.

This pattern suggests that the tax treatment of UK pension funds may well have been influential, at least for company decisions on the form in which to pay dividends to their shareholders. It also identifies a group of firms whose behaviour was particularly consistent with the tax preference of UK pension funds - namely those firms that switched to paying FIDs after July 1997, and who could have paid FIDs but chose not to in the earlier period.

We investigate whether either of the level of dividends paid by this group of firms, or their investment spending, changed significantly after 1997, relative to a control group of companies that did not have foreign profits and hence could not pay FIDs in either period.

We find that the level of dividends paid increased significantly for the group of 'switchers', whose choices on the form of dividends paid suggest influence from UK pension funds at least in the pre-reform period. We find no significant effect on their level of investment. The same patterns are found relative to a control group of all other quoted non-financial companies.

These findings are consistent with the 'new view' of dividend taxation. The firms that switched from paying ordinary dividends to paying FIDs after the tax reform in July 1997 made a tax saving at the corporate level. According to the 'new view', this tax saving would be passed on to shareholders as higher dividends, with no implications for investment.

This raises the question of why these firms did not choose to make the same tax saving in the period before July 1997. Our interpretation is that their dividend policies were influenced by the tax preference of UK pension providers. But if this is correct, it suggests that these firms may not have been maximising their stock market valuations. Shares in UK companies are traded internationally, and in essence are valued at what they are worth to foreign investors. For firms that later switched, the payment of FIDs was likely to have been tax efficient from the perspective of foreign investors also in the period before July 1997. Consistent with this, we find that there was a significant increase in the stock market valuation of these firms in the two months after the July 1997 Budget. While there may be other explanations for this pattern, it is consistent with the hypothesis that large local institutions such as pension funds can influence at least the financial behaviour of UK companies, even when this imposes tax costs on other investors, and even when this results in a lower stock market valuation. 


\section{Introduction}

Recent changes to the taxation of company dividends in the UK provide an opportunity to investigate empirically how dividend taxes affect firms' dividend policies, cost of capital and investment. Prior to July 1997, the UK tax system was unusual in that a major class of shareholders - UK pension funds, and insurance companies managing pension-related assets - had a more favorable tax treatment of dividend income than capital gains. Tax credits, which reduced personal income tax on dividends for taxpaying shareholders, were repaid to these tax-exempt funds. This position changed sharply in July 1997. Although dividend tax credits remained for taxpayers, they were no longer refundable to UK pension funds and insurance companies. After July 1997, these institutional investors had an equal tax treatment of dividend income and capital gains. This paper studies the effects of this tax reform on the dividend payments and investment spending of quoted non-financial UK companies.

In a companion paper, we argue that domestic dividend taxation has little or no effect on the stock market valuation of UK companies. This reconciles the fact that pension funds and insurance companies owned around half the equity in quoted UK firms before July 1997, and the fact that there was no sharp fall in the UK stock market around the time when these repayable tax credits were abolished. The theoretical argument is straightforward and consistent with standard asset pricing models when investors have heterogeneous tax rates. ${ }^{1}$ All investors holding some, but not all, of their wealth in an asset must agree on the value of their marginal holding. When a small group of investors has a more favorable tax treatment for a particular risky asset, they will hold more of that asset, up to the point where the additional risk that they bear just balances the tax advantage. This will have a significant effect on the price of the asset only if the wealth controlled by this group of investors is large relative to the international capital market. Essentially this says that UK equities are priced at their value to foreign investors, which was largely unchanged

\footnotetext{
${ }^{1}$ See, for example, Brennan (1970).
} 
by the July 1997 tax reform. After July 1997, UK pension funds diversified out of UK equities, and foreign investors increased their holdings, with little or no impact on prices. Bond, Devereux and Klemm (2005) provides more detail and empirical evidence consistent with these predictions.

If all firms chose their dividend policies simply to maximise their stock market valuations, that would be the end of the story. However we document that there were significant changes to the form in which UK companies chose to pay dividends, immediately after this tax change in July 1997. At that time, UK multinationals with profits earned outside the UK could elect to pay dividends in a special form, known as Foreign Income Dividends (FIDs), which could permit a tax saving for the firm. Before July 1997, FIDs were less attractive than ordinary dividends for UK pension funds, because they did not provide a refundable tax credit. After July 1997, this relative disadvantage was eliminated by the abolition of refundable tax credits on ordinary dividends. Importantly, the tax treatment of both FIDs and ordinary dividends was unchanged for all other shareholders. However both the number of firms paying FIDs and the proportion of total dividends paid in the form of FIDs increased sharply after July 1997. This is consistent with some influence of UK pension funds over at least this aspect of dividend policies for a group of UK firms.

Given this, we investigate whether this tax reform had further effects on either the level of dividend payments or on the level of investment. We identify a group of quoted non-financial UK companies that could have paid FIDs in the period before July 1997 but who chose not to do so, consistent with the tax preference of UK pension funds prior to the abolition of refundable tax credits on ordinary dividends. We then ask whether dividend payments or investment changed for this group, relative to a 'control group' of all other quoted non-financial UK firms. In making these comparisons, we distinguish between those firms that switched to paying FIDs after July 1997, and those firms that continued not to pay FIDs. This distinction is important because the group that switched to paying FIDs enjoyed a tax saving at the corporate level which other firms did not. We find evidence that this group increased their dividend 
payments after July 1997, suggesting that some or all of this corporate tax saving was paid out to shareholders as higher dividends. We find no clear evidence of any change in dividend payments for other firms whose reluctance to pay FIDs before July 1997 indicates that they may have been subject to influence from UK pension funds. We also find no evidence of changes in investment spending for either of these groups.

These results are consistent with a version of the 'new view' or 'trapped equity' model of dividend taxation, developed by King (1974) and Auerbach (1979). We present a simple model in the appendix which predicts that a reduction in dividend taxes paid by firms will increase dividends paid to shareholders, while an increase in dividend taxes paid by shareholders will have no effect on dividends or investment. However we acknowledge that our tests may have low power to reject these predictions of the 'new view' against reasonable alternatives. We rely partly on an assumption that all firms which could have paid FIDs before July 1997 and chose not to do so were more likely to be influenced by UK pension funds than firms which did not have the option to pay FIDs. This test would have no power if UK pension funds were equally likely to influence both groups of firms.

Perhaps the most interesting aspect of our results is the identification of a group of UK companies that switched from not paying FIDs to paying FIDs immediately after this tax reform in July 1997. This implies a saving in tax at the corporate level, which can account for the observed increase in their dividend payments. Almost certainly, many of these firms could have enjoyed the same tax saving in the period before July 1997, but chose not to take advantage of this, presumably in the interest of UK pension funds. Yet if the tax treatment of UK pension funds has little or no impact on firms' share prices, this would imply that these firms were not maximising their stock market valuations in the period before July 1997. To test this, we consider how the share prices of this group of firms reacted to the abolition of refundable dividend tax credits in July 1997. After a small initial fall, we find a significant increase in their share prices, relative to those of other quoted non-financial UK companies, around one month after the tax reform. While not conclusive, this is consistent with the 
suggestion that large institutional shareholders can influence at least the financial behaviour of large corporations, even when this is clearly disadvantageous for other shareholders, and even when this results in a lower valuation of the company on the stock market .

The remainder of the paper is organised as follows. Section 2 describes relevant aspects of UK dividend taxation over the period of our study, and presents evidence on the increased use of Foreign Income Dividends after July 1997. Section 3 summarises theoretical predictions about the possible effects of these tax changes, with a formal model presented in the appendix. Section 4 presents our main empirical evidence on the levels of dividends and investment, while section 5 presents a simple event study analysis of how this tax reform affected share prices for different groups of firms. Section 6 concludes.

\section{UK dividend taxation, before and after July 1997}

The tax treatment of UK dividends in the 1990s was complex, and changed significantly in July 1994, July 1997 and April 1999. Our review in this section focuses on the features that are particularly important for the empirical analysis in this paper.

Between April 1973 and July 1997, the UK operated a standard form of partial imputation system, with dividend tax credits for domestic shareholders providing tax relief against personal income tax in recognition of part of the corporate income tax paid by UK firms. ${ }^{2}$ The rate of these credits fell in line with the basic rate of UK income tax, from $33 \%$ in 1979 to $25 \%$ in 1989, and was further cut to $20 \%$ (below the basic rate of income tax) in $1993 .{ }^{3}$ Still these credits implied that each $£ 1$ in cash dividends had a value of $£ 1.25$ to tax-exempt shareholders, before they were

\footnotetext{
${ }^{2}$ Depending on bilateral tax treaties, foreign shareholders may have benefited to a small extent from these tax credits on dividends paid by UK firms. Importantly, this benefit was not reduced by the July 1997 tax reform that we study here, although it may have been reduced by the later reform in April 1999.

${ }^{3}$ The income tax rate on dividends for basic-rate taxpayers was cut to $20 \%$ at the same time, so the main effect of this change was to reduce the value of dividend tax credits paid out to tax-exempt shareholders.
} 
made non-refundable in July 1997. ${ }^{4}$ This tax reform reduced the value of a given cash dividend payment to UK pension funds by $20 \%$, and was estimated to save the UK government around £5bn annually, close to $20 \%$ of total corporate income tax receipts.

These dividend tax credits were at least nominally financed by Advance Corporation Tax (ACT), a tax paid by firms at the time that dividends were paid to their shareholders. For most firms, this was simply a pre-payment of the corporate income tax, and could be reclaimed in full a few months later when the annual payment of (mainstream) Corporation Tax was made. However there was an asymmetry in this system which affected firms whose dividend payments were high relative to their UK taxable profits. Such firms could find themselves in a position where recovery of their ACT payments was deferred, so that ACT acted at least in part as an additional tax.

This asymmetry, known as unrelieved or surplus ACT, particularly affected UKbased multinational firms. These firms earn profits and pay corporate income taxes abroad, so that their UK taxable profits could appear to be low relative to their worldwide operations and dividend payments. Following lobbying from these firms, a special class of dividend payments with a different tax treatment was introduced in July 1994. Firms with foreign profits could opt to pay Foreign Income Dividends (FIDs). ${ }^{5}$ Advance Corporation Tax paid on FIDs could be reclaimed in the same year, regardless of the level of UK taxable profits. This could represent a significant tax saving for firms where recovery of ACT payments on ordinary dividends could not be anticipated in the foreseeable future.

At the shareholder level, the tax treatment of FIDs was equivalent to that of ordinary dividends for taxpaying shareholders, but not for tax-exempt shareholders. Although there were no tax credits on FIDs, they were taxed more favorably under the personal income tax, so that in effect there was the same tax treatment for

\footnotetext{
${ }^{4}$ The credit was expressed as $20 \%$ of the 'grossed-up' value of the dividend (i.e. the cash dividend plus the tax credit).

${ }^{5}$ Firms with foreign income could choose to pay ordinary dividends, FIDs or both. If FIDs were paid, they had to be paid to all shareholders.
} 
taxpaying shareholders. However, for tax-exempt shareholders, there was a significant disadvantage. As there were no tax credits on FIDs, there was nothing to be repaid to tax-exempt shareholders. Each $£ 1$ received as a FID was thus worth $£ 1$ to tax-exempt shareholders. This meant that, prior to July 1997, £1 received as a FID was worth substantially less to these shareholders than $£ 1$ received as an ordinary dividend with a repayable tax credit attached.

Considering both corporate and shareholder level taxes, this implied that for firms with unrelieved ACT and foreign income, who could save tax by paying FIDs rather than ordinary dividends, ${ }^{6}$ the payment of FIDs rather than ordinary dividends was strictly tax-efficient for taxpaying shareholders. The firm saved tax because all ACT paid on FIDs could be recovered without delay, and there was no disadvantage at the personal level for taxpaying shareholders. However, except in an extreme position, the payment of FIDs rather than ordinary dividends was strictly tax-inefficient for UK pension funds in the period from July 1994 to July 1997. The value of the tax credit foregone by these shareholders if the firm paid FIDs was at least as high as the tax saved by the firm, and they could only be equal if there was no prospect of ever recovering any part of the ACT payment.

Table 1 summarises the tax treatment of ordinary dividends and FIDs for two different types of shareholders. In each case, the table shows the net dividend received after all taxes when the firm raises $£ 1$ by issuing new shares, and pays out the proceeds, either as an ordinary dividend or as a FID. Since a FID can only be paid out of foreign income, we consider the case in which the $£ 1$ raised is used to purchase $£ 1$ of new shares in a foreign subsidiary, with $£ 1$ of this subsidiary's profits being paid back to the parent, before being distributed to the shareholders. We ignore transactions costs.

Before July 1997, if the shareholder is a UK pension fund, the net value of an ordinary dividend financed in this way can be expressed as $1.25-0.25 \alpha$, where $\alpha$

\footnotetext{
${ }^{6}$ Not all firms with unrelieved ACT and foreign income could make a net tax saving by choosing to pay FIDs, as there may have been offsetting effects on their UK corporation tax charge. We discuss this further below.
} 
is a parameter that varies between 0 and 1 depending on the firm's surplus ACT position. For a firm that is unaffected by surplus ACT, $\alpha=0$, while for a firm that is in the extreme position with no chance of ever recovering any additional payment of ACT, $\alpha=1 .^{7}$ After July 1997, the abolition of refundable dividend tax credits on ordinary dividends for UK pension providers reduces this value to $1-0.25 \alpha$. In both periods the dividend received by a UK pension fund if the firm instead pays out the proceeds in the form of a Foreign Income Dividend is $1-\beta$, where $\beta \geq 0$ is a parameter that reflects any UK corporation tax incurred through the additional repatriation of profits from the subsidiary. ${ }^{8}$ Similarly, if the shareholder is a basic rate UK taxpayer, the value of the dividend received both before and after this tax reform would be $1-0.25 \alpha$ if the firm pays an ordinary dividend, and $1-\beta$ if the firm pays a FID.

It is clear from Table 1 that, prior to the reform, a UK pension fund would have strictly preferred to receive income in the form of a FID rather than an ordinary dividend only if $\alpha>1+4 \beta$. However, since $\alpha \leq 1$ and $\beta \geq 0$, this could not be the case. Only at the extreme of $\alpha=1$ and $\beta=0$ would the pension fund have been indifferent between the two types of dividend. After July 1997, however, the UK pension fund would strictly prefer income in the form of a FID if $\alpha>4 \beta$, a condition which may or may not hold, depending on the firm's surplus ACT position and the cost of repatriating foreign income. Indeed this is exactly the same condition that determined the tax preference of basic rate taxpayers throughout this period.

It follows that the only change directly brought about by the 1997 reform is in the preferences of UK pension funds. They would have preferred ordinary dividends to FIDs prior to 1997, but - depending on $\alpha$ and $\beta$ - may have preferred FIDs to

\footnotetext{
${ }^{7}$ Abstracting from uncertainty about the delay before an additional ACT payment could be recovered against the firm's corporation tax liability, this parameter can be expressed as $\alpha=1-$ $\left(\frac{1}{1+r}\right)^{n}$, where $n$ is the number of periods before ACT payments are recovered, and $r$ is a discount rate.

${ }^{8}$ This could be significant, for example, if the foreign profits were earned by a subsidiary located in a jurisdiction with a much lower corporate income tax rate than that in the UK. The value of $\beta$ is thus likely to vary considerably across firms.
} 
ordinary dividends after 1997. Basic rate taxpayers and other shareholders may have preferred FIDs prior to 1997; importantly there was no change in their preferences as a result of the 1997 reform. Changes in the form in which dividends were paid after this tax reform would therefore be consistent with UK pension funds influencing the dividend behaviour of UK companies. Note also that, assuming pension funds received ordinary dividends before the tax reform, the net income they received from each $£ 1$ of dividends paid must fall after the reform. This is true whether or not the firm switches the form of its dividend payment. In other words, there is an effective increase in dividend taxation for UK pension funds, but not for other shareholders.

Table 2 reports how many quoted UK companies paid FIDs in the period from July 1994 until their abolition in April 1999. ${ }^{9}$ Prior to July 1997, fewer than fifty firms were opting to pay FIDs. We cannot be certain how many firms were entitled to do so, but based on information in company accounts about payment of foreign corporate taxes, we estimate that only around $5 \%$ of quoted UK firms with foreign income were choosing to pay FIDs. Immediately after the abolition of repayable tax credits on ordinary dividends for UK pension funds, however, the number of firms paying FIDs almost trebled, as did the proportion of firms with foreign income that chose to pay FIDs. We stress that the only shareholders who were affected by the abolition of repayable tax credits in July 1997 were UK pension funds and pension assets managed by insurance companies.

Figures 1 and 2 present quarterly data on the number of FID payments as a fraction of all dividend payments, and on the value of FID payments relative to the value of all dividend payments. The proportion of dividend payments taking the form of FIDs was increasing a little before July 1997, but jumped to a new higher level immediately after the tax reform. The share of dividends paid as FIDs was more stable at under 10\% before July 1997, and increased to around 30\% in 1998.

There are other possible reasons why the use of FIDs may have increased after

\footnotetext{
${ }^{9}$ Both Advance Corporation Tax and Foreign Income Dividends were abolished in April 1999. Further technical changes were made to dividend tax credits at that time, but domestic shareholders were largely unaffected by these changes.
} 
July 1997. The abolition of FIDs with effect from April 1999 was announced in the July 1997 Budget, at the same time as the abolition of repayable dividend tax credits for UK pension funds. Some firms that had planned to pay FIDs at a later date may have brought forward FID payments as a result. In general it is not clear why firms that would save tax by paying FIDs rather than ordinary dividends should delay doing so, although expectations of how dividends would be taxed after April 1999 could provide some explanation. ${ }^{10}$ Another possibility is that some firms had delayed paying FIDs in the period from July 1994 to July 1997, correctly anticipating that changes to the tax treatment of ordinary dividends would reduce the opposition of UK pension funds to income in the form of FIDs in the near future.

We do not observe the ideal comparison between dividend behaviour in worlds where dividend taxation is fixed forever under the regimes that applied immediately before and after July 1997. Hence we can only conclude that the sharp increase in the use of FIDs immediately after July 1997 is consistent with some influence of UK pension funds over the dividend behaviour of UK companies, at least in the period before the abolition of repayable dividend tax credits in July 1997.

Nevertheless we regard this as prima facie evidence that the form in which some UK companies chose to pay dividends may have been affected by the tax preference of UK pension funds. This in turn suggests the possibility that their dividend policies more generally may have been influenced by the tax treatment of this class of shareholders. To test this, we can investigate whether the abolition of repayable dividend tax credits in July 1997 - which represented a significant increase in the taxation of dividends for these shareholders - affected the level of dividends paid by these firms.

More precisely, we consider a group of firms that could have paid FIDs in the pre-reform period but chose not to do so. These are firms which, in the period

\footnotetext{
${ }^{10}$ How dividends were to be taxed after April 1999 did not become clear until the Pre-Budget Report of November 1998. The abolition of Advance Corporation Tax and details of the "shadow ACT' regime proposed in November 1998 gave firms that could do so an incentive to pay FIDs rather than ordinary dividends in the short period between November 1998 and April 1999. Although in fact the share of dividends paid in the form of FIDs began to decline during this period (see Figure 2).
} 
between July 1994 and July 1997: a) reported paying foreign corporate taxes; b) paid dividends; and c) did not pay Foreign Income Dividends. These criteria select a group of firms whose dividend policies were particularly tax-efficient for UK pension funds. In Section 4 we investigate changes in these firms' dividend and investment behaviour, before and after the July 1997 tax reform, relative to other UK companies. In doing this, we distinguish between the subset that switched to paying Foreign Income Dividends in the period between July 1997 and April 1999, and those that did not. The former group are likely to have made a net tax saving at the corporate level, which the latter group clearly did not. As we explain in the next section, this corporate tax saving may also have affected their dividend and investment decisions. First we review theoretical arguments why an increase in dividend taxation for a relevant group of shareholders may or may not affect firms' dividend choices or their cost of capital.

\section{Alternative views of dividend taxation}

The 'new view' or 'trapped equity' model of dividend taxation, developed by King (1974) and Auerbach (1979), predicts that a change in the level of dividend taxation ${ }^{11}$ paid by shareholders has no effect on either dividends or the cost of capital, at least for firms who are paying dividends and whose marginal source of finance for investment is retained earnings (i.e. lower dividend payments). This assumes that shareholders face a higher tax rate on dividend income than on capital gains. A 'round trip' which involves issuing one additional unit of new equity and paying out one additional unit of dividends therefore imposes an unnecessary tax charge on shareholders.

Abstracting from factors other than taxation, this makes retained earnings a cheaper source of finance than new share issues. The tax-efficient financial policy is to fund investment by reducing dividends, issuing equity only if attractive investment opportunities exceed the firm's current cash flow. Dividends are paid if cash

\footnotetext{
${ }^{11}$ Throughout this section, our analysis relates to a change in dividend taxation that is both unanticipated and assumed to be permanent.
} 
flow exceeds attractive investment opportunities, but are determined as the residual. For investment financed by retained earnings, the shareholder gives up dividends today in return for higher dividends in the future. Provided the tax rate on dividends is constant, this lowers both the cost of the investment and the return on the investment in the same way, and has no effect on the cost of capital (i.e. the required rate of return from the marginal investment project). Thus neither investment nor dividends (the difference between cash flow and investment) depend on the rate of dividend taxation paid by shareholders. In effect, dividends are minimised at any tax rate higher than the effective rate on capital gains, and are insensitive to the level of dividend taxation within this region.

Applying this analysis to a case where the relevant shareholder faces a lower tax rate on dividends than on capital gains produces uncomfortable predictions. The round trip of issuing equity to pay out dividends becomes a one-way bet. UK pension funds do not pay income tax on dividends or capital gains, but prior to July 1997 they received a repayable tax credit on dividends from UK firms. By issuing $£ 1$ of new equity, a firm could pay a cash dividend of $£ 1$, which as explained in the previous section was worth $£ 1.25$ to UK pension funds. ${ }^{12}$ A firm choosing dividend policy in the interest of UK pension funds thus had a strong incentive to issue new equity to pay out high dividends. Abstracting from the additional tax cost at the corporate level imposed by surplus Advance Corporation Tax, the optimal levels of both new issues and dividends would appear to be infinite. Even recognising the presence of surplus $\mathrm{ACT}$, the optimal policy would appear to involve issuing equity to pay dividends up to the point where the probability of ever recovering the ACT payment on the last unit of dividends was driven down to zero. ${ }^{13}$

These incentives changed sharply after July 1997. UK pension funds now had no

\footnotetext{
${ }^{12}$ The value of each unit of cash dividends $D$ can be expressed as $\gamma D$, where $\gamma=1 /(1-c)>1$ and $c=0.2$ is the rate of the tax credit.

${ }^{13}$ Only in this extreme case did the additional tax cost imposed by surplus ACT fully offset the tax credit on dividends paid to tax-exempt shareholders. Devereux, Keen and Schiantarelli (1994) provide a rigorous analysis of optimal financial policies for firms in this context.
} 
strict tax preference for dividend income rather than capital gains. Indeed for firms that had previously accumulated a stock of surplus ACT, the payment of ordinary dividends became strictly tax inefficient. By minimising ordinary dividends, such firms could maximise the rate at which past ACT payments could be recovered against their current corporate income tax liabilities.

This analysis thus predicts that at least some firms whose dividend policies had previously been influenced by the tax treatment of UK pension funds would choose lower dividend payments, at least temporarily, in the period after the abolition of repayable tax credits in July 1997. However we are skeptical about the extreme financial policies that are predicted. While many UK firms did accumulate surplus Advance Corporation Tax, this was typically due to earning profits outside the UK, rather than to excessive new equity issues. We are also doubtful about the implication that financial policies would be indeterminate in the absence of distortionary taxes.

In the appendix we outline a simple formal model in which there are also non-tax costs and benefits associated with the payment of dividends. ${ }^{14}$ More specifically, in the spirit of Rozeff (1982), we assume that the use of new equity finance may increase the efficiency with which investment projects are managed, by subjecting investment decisions to scrutiny and monitoring from the external capital market. This can explain why firms may choose to issue new equity and pay out dividends at the same time. ${ }^{15}$ At the same time we assume that transaction costs are incurred when firms issue new shares. ${ }^{16}$ This can explain why retained earnings may remain the cheapest source of finance, even if relevant shareholders have a tax preference for dividend income over capital gains, as was the case for UK pension funds prior to July 1997.

Provided these transaction costs are high enough, this model can generate similar

\footnotetext{
${ }^{14}$ Earlier papers that present interesting extensions to the basic 'new view' model include Poterba and Summers (1985) and Auerbach and Hassett (2002).

${ }^{15}$ In the sample of quoted non-financial UK companies that we analyse in section 4 , dividends are paid in $96 \%$ of the accounting periods in which firms issue new shares.

${ }^{16}$ More loosely, we can think of these transaction costs as representing any costs associated with issuing outside equity, such as the signalling cost emphasised by Myers and Majluf (1984) in an asymmetric information context.
} 
predictions about the effects of dividend taxes as those associated with the standard version of the 'new view' or 'trapped equity' model. If small changes in the level of new share issues generate no additional efficiency benefits, an increase in dividend taxes levied on shareholders will have no effect on either the level of new issues or the level of investment chosen by dividend-paying firms, and consequently will have no effect on the level of dividend payments.

However this model also suggests mechanisms through which such dividend taxes could affect dividends or investment, even for dividend-paying firms. For example, an increase in dividend taxation raises the cost of using new equity finance. If small changes in the level of new issues do generate additional efficiency benefits, the firm will trade off these gains against the cost of issuing equity. A higher cost of issuing equity will thus induce the firm to choose a lower level of new issues. If this has no implications for investment, this results in a lower level of dividend payments, as the firm relies less on new issues and more on retained profits to finance its investment spending. If reduced reliance on external finance also reduces the marginal profitability of additional investment spending, this increase in the cost of issuing new equity may also result in a lower level of investment.

As in the standard 'new view' model, there is also a regime in which dividends are zero, and firms rely exclusively on new share issues to finance additional investment spending. For investment financed by new share issues, an increase in dividend taxation lowers the return to shareholders in the form of future post-tax dividend income, with no offsetting effect on the cost to shareholders of financing this investment. In this case we get the standard result that an increase in dividend taxation raises the cost of capital and results in a lower level of investment.

This more general model thus suggests that an increase in dividend taxation for a relevant group of shareholders could reduce both dividends and investment. Dividends would fall for dividend-paying firms if the higher tax cost of paying dividends induces firms to reduce their reliance on new share issues. Investment would fall for dividendpaying firms if the more limited use of finance from the external capital market reduces 
the marginal profitability of investment. Alternatively, as predicted by the standard 'new view' model in the case where dividends are taxed more heavily than capital gains, an increase in dividend taxation for a relevant group of shareholders could have no effect on either dividends or investment, at least for dividend-paying firms, if neither of these mechanisms is important.

It is also important in the context of UK dividend taxation in the 1990s to consider the effects of dividend taxes levied on firms. Surplus Advance Corporation Tax acted, at least in part, as a corporate tax charged on the payment of ordinary dividends. Firms that switched from paying ordinary dividends to paying Foreign Income Dividends following the abolition of repayable dividend tax credits for UK pension funds thus saved tax at the corporate level. ${ }^{17}$ In both the standard 'new view', and in the corresponding special case of our more general model, it is relatively straightforward to derive the implications of a reduction in dividend taxes levied on firms. The residual left when desired investment has been financed from earnings plus desired new share issues (if any) is now not paid out entirely as cash dividends to shareholders, but is paid out partly as cash dividends to shareholders and partly in the tax on these dividends paid by the firm to the government. A reduction in this tax implies a straightforward transfer from tax payments to dividend payments. Thus a saving in corporate tax on dividend payments is expected to result in an increase in cash dividends paid to shareholders. In richer versions of our model, this effect could be reinforced by an increase in the level of new equity issues induced by the lower tax cost of paying dividends.

We have been careful in this section to discuss the tax treatment of 'relevant' shareholders, without being specific about the identity of these shareholders in cases where different types of shareholders face different tax rates. We have argued in the

\footnotetext{
${ }^{17}$ There are two reasons why we cannot be sure how much tax was saved by individual firms. First, only part of their ACT payments on ordinary dividends may have been irrecoverable. Second, payment of FIDs may have triggered an increase in UK corporate income tax. We can however be reasonably confident that these firms enjoyed some net tax saving, as they could have chosen not to pay FIDs otherwise.
} 
introduction that the tax treatment of UK pension funds has little or no effect on the stock market valuation of quoted UK companies, so that if dividend policies are chosen to maximise share prices, we would not expect the taxation of pension funds to be relevant. However we have presented evidence in the previous section which suggests that at least the form in which UK companies paid dividends may have been influenced by the tax treatment of UK pension funds. We do not attempt to resolve here how firms should behave when different shareholders have conflicting tax preferences. In the next section, we investigate how UK firms did behave in response to the abolition of repayable dividend tax credits for UK pension funds.

\section{Evidence on dividend payments and investment}

We study the dividend and investment behaviour of a sample of 696 quoted nonfinancial UK companies in the period 1994-2001. More precisely, our sample includes accounting periods that end between January 1994 and December 2001, and we require at least one observation on each firm to fall within the pre-reform and postreform periods. Data on these firms is obtained from Thomson Financial Datastream.

\subsection{Dividends}

We estimate simple econometric models to explain the level of these firms' dividend payments, controlling for their reported profits and sales. Our main objective is to investigate whether there was any change in dividend behaviour after the July 1997 tax reform, particularly for firms whose prior dividend choices suggest that they may have been influenced by the tax treatment of UK pension funds. Our regression models thus have the general form

$$
\text { Div }_{i t}=\text { Controls }_{i t} \beta+\text { Dummies }_{i t} \delta+\varepsilon_{i t}
$$

where $D i v_{i t}$ is the level of dividends paid by firm $i$ in period $t$, Controls $_{i t}$ is a vector of current or lagged control variables including profits and sales, ${ }^{18}$ and Dummiesit is

\footnotetext{
${ }^{18}$ We also consider controlling for unobserved, time-invariant firm-specific 'fixed' effects.
} 
a vector of dummy variables indicating whether the period is before or after the tax reform and whether we classify the firm as belonging to a group that was more or less likely to be influenced by the tax treatment of UK pension funds.

Quoted UK companies typically pay dividends twice a year, with a relatively small interim dividend being paid during the accounting period, and a relatively large final dividend being paid when profits are reported. Our measure of dividends includes both these payments, or more generally, includes all cash dividend payments that are declared to be paid out of the profits reported for accounting period $t .{ }^{19}$ This includes any payment of Foreign Income Dividends. Our measure of profits (Profits (Pt $_{\text {) }}$ is net of depreciation, interest, taxes, exceptional items and preference dividends. ${ }^{20}$ Our measure of firm size is total sales $\left(\right.$ Sales $\left._{i t}\right){ }^{21}$

Datastream provides the exact dates on which all dividend payments are made. We use this information to classify company accounts to the post-reform period only if all dividend payments occurred after the tax change on 2 July 1997. All other accounts are classified to the pre-reform period, even if some of the related dividend payments fell after this date. ${ }^{22}$ The dummy variable Post $97_{t}$ takes the value one for accounts classified to the post-reform period, and zero otherwise.

As explained in section 2, we use the choice of not paying Foreign Income Dividends (FIDs) in the period between July 1994 and July 1997 as indicating a group of firms whose dividend behaviour may have been influenced by the tax preference of UK pension funds. More precisely we first define the dummy variable $N_{o F I} D_{i}$ to be equal to one if firm $i$ paid no FIDs between July 1994 and July 1997, and if in the pre-reform period we observe that the firm paid ordinary dividends and reported paying foreign corporate taxes (suggesting that it had foreign activities and could have

\footnotetext{
${ }^{19}$ This corresponds to item 187 in Datastream's classification of the profit and loss account.

${ }^{20}$ This corresponds to item 625 (earned for ordinary) in Datastream's classification of the profit and loss account.

${ }^{21}$ Item 104 (total sales) in Datastream's classification of the profit and loss account.

${ }^{22}$ Broadly similar results were obtained if we classify to the pre-reform period only those accounts for which all dividend payments occurred before 2 July 1997. Typically this results in one additional year being allocated to the post-reform period for each firm.
} 
chosen to pay dividends in the form of FIDs). We then divide the group of firms with NoFID $D_{i}$ equal to one into those firms that continued not to pay FIDs in the postreform period (NeverFID $=1)$ and those that switched to paying FIDs after the abolition of repayable dividend tax credits for UK pension funds $\left(\right.$ FIDswitch $\left.{ }_{i}=1\right)$.

Notice that these dummy variable are time-invariant, so that we use choices made by the firm in the pre-reform period to indicate possible influence from UK pension funds at that time. This is sufficent for the purpose of our test. That is, if these firms change their dividend behaviour after July 1997, we are not concerned whether this is because they are still influenced by UK pension funds and the tax preference of UK pension funds has changed, or because they are no longer influenced by UK pension funds after July $1997 .^{23}$

Our interest centres on the interaction terms Post $97_{t} *$ NeverFID $D_{i}$ and Post $97_{t} *$ FID switch ${ }_{i}$. These dummy variables pick out observations in the post-reform period on the groups of firms whose dividend behaviour, at least prior to the reform, may have been influenced by the tax treatment of UK pension funds. Given that we include both these interaction terms and a basic post-reform dummy (Post97 $\left.t_{t}\right)$ in our specifications, the coefficient on Post $97_{t} *$ NeverFID $D_{i}$ tests whether or not there was any differential change in dividend payment behaviour after the tax reform for firms that chose not to pay FIDs both before and after the reform; and the coefficient on Post $97_{t} *$ FIDswitch $i$ tests whether or not there was any differential change in dividend payment behaviour after the tax reform for firms that chose not to pay FIDs before the reform and switched to paying FIDs after the reform.

The null hypothesis that the coefficients on both these interaction terms are zero corresponds to the case in which any change in dividend behaviour after July 1997 is common to all quoted non-financial UK firms. A significant negative coefficient on ${\text { Post } 97_{t} * \text { NeverFID }}_{i}$ would indicate that, given profits and sales, dividend payments

\footnotetext{
${ }^{23}$ As discussed in more detail in Bond, Devereux and Klemm (2005), ownership of quoted UK equity by UK pension funds fell sharply after July 1997. The Office for National Statistics estimates that the fraction of quoted UK equity owned by UK pension funds fell from $28 \%$ in December 1994 to $18 \%$ in December 2000.
} 
fell on average for the firms that chose never to pay FIDs, relative to firms that could not pay FIDs because they had no foreign income. A significant positive coefficient on ${\text { Post } 97_{t} * \text { FID switch }}_{i}$ would indicate that, given profits and sales, dividend payments increased on average for the firms that chose not to pay FIDs in the pre-reform period and switched to paying FIDs in the post-reform period, relative to the same group of other quoted non-financial UK companies.

Formally these can be interpreted as 'difference-in-differences' tests, in which those firms that chose never to pay FIDs and those firms that switched after July 1997 are classed as 'treatment groups' and the remaining firms are classed as the 'control group'. We note that there may be substantial classification error in our assignment of firms to these groups, in the sense that not all the firms who chose not to pay FIDs in the pre-reform period will have done so because they were influenced by UK pension funds, and UK pension funds may have influenced the dividend behaviour of some firms that had no foreign profits and so were not eligible to pay FIDs.

This will certainly weaken the power of our tests, but our tests remain consistent provided that any firms who were influenced by the tax treatment of UK pension funds are more likely to be in one of our treatment groups than in our control group. This assumption is probably more reasonable in the case of firms that switched behaviour after the tax reform, since the change in the tax treatment of UK pension funds is likely to have been one of the main reasons why the popularity of FID payments increased after July 1997. It is possibly more debatable in the case of firms that continued not paying FIDs after July 1997. At first sight, the fact that these firms did not switch to paying FIDs after this tax reform might suggest that there were other reasons why these firms had not paid FIDs in the pre-reform period. However, firms that were influenced by UK pension funds, paid high ordinary dividends, and encountered surplus ACT in the period before July 1997, could respond in one of two ways after July 1997. They could avoid the additional tax cost imposed by surplus ACT either by switching from ordinary dividends to FIDs, or they could just reduce payments of ordinary dividends. In the former case, they would be in our 
group with $F I D$ switch $_{i}=1$, but in the latter case they would be in our group with NeverFID $D_{i}=1$.

It should also be noted that the assignment of firms to these groups is far from random. To be eligible to pay FIDs, firms must have foreign activities, and therefore tend to be large. Table 3 reports some basic descriptive statistics for the 690 firms that we observe with accounting periods ending in 1997. The median firm in our treatment group that chose never to pay FIDs has sales that are twice as high as the median firm in our control group, whilst the median firm in our treatment group that switched to paying FIDs has sales that are eighteen times higher than the median firm in our control group. These differences in size are even greater when we consider profits and dividends. This illustrates the importance of controlling for differences in size and profitability before inferring that any differential changes in dividend payments after the 1997 tax reform are attributable to changes in the tax treatment of dividends introduced by that reform.

The residuals $\left(\varepsilon_{i t}\right)$ in specifications like $(1)$ were found to be severely heteroskedastic. We report weighted least squares estimates, in which the variance of these residuals is assumed to be proportional to the square of current sales. ${ }^{24}$ Ordinary least squares coefficients were generally of the same sign, but estimated much less precisely. Very similar results were obtained using a weighted Tobit maximum likelihood estimator to account formally for the presence of firms paying zero dividends. ${ }^{25}$

Table 4 reports estimates of two basic models, with and without controlling for unobserved firm-specific effects. Columns (i) and (ii) include only current levels of our profits and sales variables. Columns (iii) and (iv) also allow current dividends to

\footnotetext{
${ }^{24}$ Noting that these weighted least squares estimates of model (1) can also be interpreted as ordinary least squares estimates of the scaled model

$$
\frac{\text { Div }_{i t}}{\text { Sales }_{i t}}=\left(\frac{\text { Controls }_{i t}}{\text { Sales }_{i t}}\right) \beta+\left(\frac{\text { Dummies }_{i t}}{\text { Sales }_{i t}}\right) \delta+\frac{\varepsilon_{i t}}{\text { Sales }_{i t}}
$$

this estimator will also be less sensitive to the presence of outliers in the highly skewed distributions of profits and sales (see Table 3 for our sample, and the related discussion in Chetty and Saez (2004)).

${ }^{25}$ This is not surprising, as zero dividends are observed for only $8 \%$ of our sample.
} 
be influenced by profits from the previous period.

As expected, higher profits are associated with higher dividends, and larger firms tend to have higher dividend payout ratios. Other results are quite sensitive to whether or not we control for unobserved firm-specific effects, which in turn affects the estimated coefficients on our observed control variables, particularly those on current and lagged profits. In the specifications that do not control for unobserved heterogeneity, we find evidence both of a significantly higher increase in cash dividends for the firms that switched to paying FIDs after July 1997, and some indication of a relative reduction in cash dividends for the group of firms that could have paid FIDs but chose not to in both periods. ${ }^{26}$ However only the former of these effects is found in the specifications that control for unobserved firm-specific effects. It is also worth noting that in these more general specifications, there is no indication of a significant increase in dividend payments, given profits and sales, for our control group.

An increase in cash dividend payments for the firms that saved corporate tax by switching form ordinary dividends to FIDs is consistent both with the predictions of the basic 'new view' model, and with reasonable alternatives. We do not find robust evidence of an effect on dividend payments for the group of firms that chose not to pay FIDs both before and after July 1997. This is also consistent with the basic 'new view' prediction, although we acknowledge that this test may have low power to reject reasonable alternatives. In particular, we rely here on the assumption that UK pension funds were more likely to have influenced the dividend behaviour of this group of firms than that of firms that could not pay FIDs because they had no foreign income.

\subsection{Investment}

We use a similar approach to investigate differential changes in investment behaviour after the 1997 tax reform for these groups of firms. Our investment models have the

\footnotetext{
${ }^{26}$ The p-values of the coefficients on Post $_{9} 7_{t} *$ NeverFID $i$ are 0.093 and 0.080 in columns (i) and (iii) respectively.
} 
general form

$$
(I / K)_{i t}=\text { Controls }_{i t} \beta+\text { Dummies }_{i t} \delta+\varepsilon_{i t}
$$

where $(I / K)_{i t}$ is the rate of gross investment for firm $i$ in period $t,{ }^{27}$ the controls include current and lagged values of real sales growth and profitability, ${ }^{28}$ and the dummies are those defined in the previous section. Since both investment rates and these control variables do not vary in proportion to firm size, we here report ordinary least squares rather than weighted least squares estimates of our investment specifications.

Table 5 reports estimates of two basic models, with and without controlling for unobserved firm-specific effects. Columns (i) and (ii) include only current and lagged real sales growth controls, as suggested by a basic accelerator model. Columns (iii) and (iv) add current and lagged profitability controls, which could proxy for expectations of future profitability, or reflect a 'financial accelerator' mechanism. ${ }^{29}$

As expected, investment rates are related to both sales growth and profitability. Whether or not we control for unobserved firm-specific effects, there is also a signficant fall in investment rates on average for this sample of quoted, non-financial UK firms after 1997. However this pattern is common to all groups of firms. There is no evidence of any differential changes in investment behaviour after the abolition of repayable dividend tax credits for UK pension funds, either for the firms that chose not to pay FIDs in the pre-reform period and switched to paying FIDs in the postreform period, or for the group of firms that chose not to pay FIDs in either period.

These findings are again consistent with a version of the 'new view' model of

\footnotetext{
${ }^{27}$ Gross investment is measured as purchases minus sales of fixed capital assets (Datastream item 1026) plus any net change in fixed capital assets due to the acquisition or disposal of subsidiaries (Datastream item 479). This is scaled by an estimate of the replacement cost value of the net capital stock at the start of the period, constructed using a simple perpetual inventory formula with an assumed depreciation rate of $8 \%$ (see Bond et al. (2004) for details).

${ }^{28}$ Profitability is measured as reported net profits (earned for ordinary, Datastream item 625) scaled by total sales (Datastream item 104). Very similar results were obtained in alternative specifications in which net profits were scaled by our estimate of the net capital stock at the start of the period.

${ }^{29}$ See Bond et al. (2004) for further discussion.
} 
dividend taxation. In particular, those firms that saved tax at the corporate level by switching to pay FIDs may have used some of this tax saving to increase dividend payments, but do not appear to have increased their investment. ${ }^{30}$ Given that we do not detect significant changes in dividend behaviour for the group that chose not to pay FIDs in both periods, it is perhaps not surprising that we also find no change in their investment behaviour.

\section{Stock market valuations}

The behaviour of the firms that switched from paying ordinary dividends to paying FIDs after the abolition of repayable dividend tax credits for UK pension funds appears to be particularly interesting. The switch from ordinary dividends to FIDs suggests that these firms were in a surplus ACT position, and reduced the extent to which their ACT payments were irrecoverable by switching to FIDs. This saving in tax at the corporate level can account for the increase in their cash dividend payments, relative to other UK companies.

However it seems very likely that these firms could have enjoyed the same corporate tax saving if they had switched to paying FIDs in the period before July 1997. Our interpretation is that their reluctance to pay FIDs in the earlier period reflected the influence of UK pension funds, who would have lost out on the refundable tax credits on ordinary dividends if these firms had paid FIDs before July 1997. UK pension funds became indifferent between ordinary dividends and FIDs only after the abolition of these refundable credits in July 1997.

The choice of paying ordinary dividends rather than FIDs in the period before July 1997 was tax-inefficient for other types of shareholders if these firms were indeed in a surplus ACT position. But only when it also became tax-inefficient for UK pension

\footnotetext{
${ }^{30}$ One implication is that the investment of this group of firms did not appear to be 'financially constrained'. As we discuss further in the appendix, this is perhaps not surprising given that there are almost no observations on firms with zero dividends in this group. Also, as we noted above, this group comprises very large multinational corporations.
} 
funds, after July 1997, did we see these firms switching to paying FIDs rather than ordinary dividends.

In Bond, Devereux and Klemm (2005), we argue that the tax treatment of UK pension funds had little or no impact on the stock market's valuation of dividend income paid by UK firms. If this is right, then the dividend choices made by this group of firms would also have been tax-inefficient from the perspective of their stock market valuations. When it became clear that they could save tax, and hence pay higher cash dividends, by switching from ordinary dividends to FIDs, we would expect to see an increase in their share prices. This is expected not because the stock market valuation of a given pound paid in cash dividends changed, but because by adopting a more tax-efficient form of dividend payments, these firms were able to pay higher cash dividends. ${ }^{31}$

It is difficult to test this hypothesis directly because it is not clear how quickly after the tax reform in July 1997 the market would learn that this group of firms were able to make this tax saving. In Figure 3, we plot the difference in cumulative stock returns between the portfolio of firms that switched to paying FIDs after July 1997 and the portfolio of all other quoted non-financial UK companies, for a period of 45 trading days following the Budget statement of 2 July 1997. We report series both for cumulative total returns and for cumulative abnormal returns, where we adjust for movements in the FTSE All Share index. ${ }^{32}$ This shows that there was an initial fall in the relative value of the firms that subsequently switched to paying FIDs, which peaked around one week after the Budget. However this fall was quickly reversed and subsequently there was a substantial increase in the value of these firms, relative to other quoted non-financial companies. This rise in their stock market valuation

\footnotetext{
${ }^{31}$ For the analysis in this section, it is not essential that the tax saving was paid out immediately in higher cash dividends. It would be sufficient for the market to be aware of the tax saving and to anticipate that this would eventually be reflected in higher dividends or lower new issues.

${ }^{32}$ To implement this adjustment, we estimate a beta coefficient for each firm in the sample using data on daily stock returns for a one year period ending on 1 July 1997. The abnormal return is the actual return minus the firm's beta coefficient times the return on the FTSE All Share index for the same period. All data is obtained from Thomson Financial Datastream.
} 
became statistically significant around five weeks after the Budget, and then persisted.

This increase in the stock market valuation of these firms is consistent with the suggestion that they were previously making dividend choices in the interest of UK pension funds that were costly not only to shareholders with different tax preferences, but also having an adverse impact on their share prices. Of course this evidence is not conclusive. If the stock market had understood immediately which firms would subsequently save tax as a result of these dividend tax changes, we would have expected their share prices to increase immediately. There may have been quite different reasons why the stock market valuation of these large, multinational corporations rose relative to smaller UK companies during August 1997. Nevertheless it is interesting that for those UK firms whose dividend choices before July 1997 appeared in theory to be inconsistent with stock market value maximisation, there is some evidence that this may indeed have been reflected in lower stock market valuations than they could have achieved.

\section{Conclusions}

We have analysed the implications of the abolition of repayable dividend tax credits for UK pension funds in July 1997 for the dividend policies and investment spending of UK companies. UK dividend taxation was complex in this period, and it is important to consider the form in which dividends were paid, as well as the level of total dividend payments. We identify a group of firms that saved tax at the corporate level by switching to a particular form of dividend payments, following the equalisation of the tax treatment of these and ordinary dividends at the shareholder level for UK pension funds. For this group, we report evidence that at least part of this corporate tax saving may have been paid out as higher cash dividends. We find no evidence of any change in their investment behaviour. For other firms whose dividend choices may also have been influenced by the tax preference of UK pension funds in the period before July 1997, we find no clear evidence of any changes in dividend payments or 
investment.

These findings are consistent with a version of the 'new view' of dividend taxation. However we acknowledge that our empirical tests may have low power to reject predictions of the 'new view' against reasonable alternatives. This reflects the fundamental difficulty of identifying sub-samples whose dividend behaviour was particularly likely to have been influenced by UK pension funds in the pre-reform period; with the possible exception of those firms that switched from paying ordinary dividends to paying Foreign Income Dividends (FIDs) in the post-reform period. The level of dividends paid by this group was affected by the associated tax saving at the corporate level, as well as by the change in the tax treatment of UK pension funds.

The behaviour of this group of firms is particularly interesting, and difficult to reconcile with the objective of (stock market) value maximisation. By choosing not to pay FIDs in the pre-reform period, these firms declined an opportunity to save tax at the corporate level. This may have been tax-efficient from the perspective of UK pension funds, but was tax-inefficient from the perspective of most other shareholders. Asset pricing theory suggests that the tax treatment of UK pension funds is unlikely to be significant for the stock market valuation of UK firms, whose shares are traded internationally. Consistent with this, we observe that the stock market valuation of this group of firms rose significantly, around one month after this tax reform. While not conclusive, this is consistent with the suggestion that large institutional shareholders can influence the dividend behaviour of large corporations, even when this is disadvantageous for other shareholders, and even when this results in a lower stock market valuation. 


\section{References}

[1] Auerbach, A.J. (1979) 'Wealth maximisation and the cost of capital', Quarterly Journal of Economics, 93, 433-446.

[2] Auerbach, A.J. and Hassett, K.A. (2002) 'On the marginal source of investment funds', Journal of Public Economics, 87, 205-232.

[3] Bond, S.R. and Cummins, J.G. (2001) 'Noisy share prices and the Q model of investment', IFS Working Paper no. W01/22.

[4] Bond, S.R., Devereux, M.P. and Klemm, A. (2005) 'The effects of dividend taxes on equity prices: a re-examination of the 1997 UK tax reform', mimeo, University of Warwick.

[5] Bond, S.R., Klemm, A., Newton-Smith R., Syed, M. and Vlieghe, G. (2004) 'The roles of expected profitability, Tobin's Q and cash flow in econometric models of company investment', Bank of England Working Paper no. 222.

[6] Brennan, M.J. (1970) 'Taxes, market valuation and corporate financial policy', National Tax Journal, 23, 417-427.

[7] Chetty, R. and Saez, E. (2004) 'Dividend taxes and corporate behaviour: evidence from the 2003 dividend tax cut', CEPR Discussion Paper no. 4722.

[8] Devereux, M.P., Keen, M.J. and Schiantarelli, F. (1994) 'Corporation tax asymmetries and investment: evidence from UK panel data', Journal of Public Economics, 53, 395-418.

[9] Fazzari, S.M., Hubbard, R.G. and Petersen, B.C. (1988) 'Financing constraints and corporate investment', Brookings Papers on Economic Activity, 1988(1), 141-195.

[10] Hayashi, F. (1985) 'Corporate finance side of the Q theory of investment', Journal of Public Economics, 27,261-280.

[11] King, M.A. (1974) 'Taxation and the cost of capital', Review of Economic Studies, 41, 21-35.

[12] Myers, S.C. and Majluf, N.S. (1984) 'Corporate financing and investment decisions when firms have information investors do not have', Journal of Financial Economics, 131, 187-221.

[13] Poterba, J.M. and Summers, L.H. (1985) 'The economic effects of dividend taxation', in E. Altman and M. Subrahmanyam (eds), Recent Advances in Corporate Finance, Homewood, IL: Richard D. Irwin Publishers, 227-284.

[14] Rozeff, M.S. (1982) 'Growth, beta, and agency costs as determinants of dividend payout ratios', Journal of Financial Research, 5, 249-259. 


\section{Appendix: A simple formal model of dividends and investment}

We consider a stylised model in which the firm invests in the first period and pays out the proceeds in the form of dividends in the second period. To focus on the implications of dividend taxation for dividend payments and new share issues, we assume the firm issues no debt. We first consider a dividend tax paid by shareholders.

In the first period, the firm has a predetermined level of cash flow, denoted $C$. It invests an amount $I$, and issues new shares with a value $N \geq 0$. If shares are issued, a transaction cost $f$ per unit is paid to a third party. The firm pays a dividend of $D=C-I+(1-f) N \geq 0$. This dividend is valued by the relevant shareholder at $\gamma D$, where $\gamma \neq 1$ reflects the presence of distortionary taxes. For example, if the relevant shareholder pays income tax on dividends at rate $m$ and no tax on capital gains, we would have $\gamma=1-m<1$. If the relevant shareholder is a tax-exempt institution who receives a repayable tax credit on dividends at rate $c$, we would have $\gamma=\frac{1}{1-c}>1 .^{33}$

At a given level of investment, paying a higher dividend requires the firm to issue more shares, so the transaction cost on new share issues represents a non-tax cost of paying dividends. Whilst we model this formally as a transaction cost, we could think more loosely of this representing other costs associated with issuing outside equity, such as the signalling cost emphasised by Myers and Majluf (1984).

In the second period, the investment generates a payoff $\Pi(I, N)$, with $\Pi_{I} \geq 0$, $\Pi_{I I} \leq 0, \Pi_{N} \geq 0, \Pi_{N N} \leq 0$ and $\Pi_{I N} \geq 0$. In the spirit of Rozeff (1982), the positive dependence of this payoff on the level of new equity reflects possible 'control benefits' of subjecting the investment decision to scrutiny and monitoring from the external capital market, rather than relying on internal finance. This effect on future profits represents a non-tax benefit of paying dividends. For simplicity, this payoff in the second period is assumed to be paid out in full as a dividend, and each unit of dividends is valued by the relevant shareholder at the same value of $\gamma$ in the second

\footnotetext{
${ }^{33}$ This treatment of shareholder taxes is standard in the 'new view' literature. See, for example, King (1974) and Auerbach (1979).
} 
period as in the first.

The firm is assumed to choose $I$ and $N$ to maximise the present value of net distributions

$$
\gamma D-N+\gamma \beta \Pi
$$

where $\beta<1$ is a discount factor, subject to non-negativity constraints on dividend payments and new share issues. Since there is no uncertainty in the model, we have $\beta=\frac{1}{1+r}$, where $r$ is the risk-free interest rate between the two periods. The firm thus maximises

$$
V=\gamma(C-I+(1-f) N)-N+\lambda^{D}(C-I+(1-f) N)+\lambda^{N} N+\gamma \beta \Pi(I, N)
$$

where $\lambda^{D}$ and $\lambda^{N}$ are shadow values associated with the non-negativity constraints. The first-order conditions for investment and new issues are respectively

$$
\begin{gathered}
V_{I}=-\left(\gamma+\lambda^{D}\right)+\gamma \beta \Pi_{I}=0 \\
\Rightarrow \Pi_{I}=(1+r)\left(\frac{\gamma+\lambda^{D}}{\gamma}\right)
\end{gathered}
$$

and

$$
\begin{aligned}
V_{N} & =\gamma(1-f)-1+\lambda^{D}(1-f)+\lambda^{N}+\gamma \beta \Pi_{N}=0 \\
& \Rightarrow \lambda^{D}(1-f)+\lambda^{N}=1-\gamma(1-f)-\gamma \beta \Pi_{N}
\end{aligned}
$$

We first consider an internal solution with strictly positive levels of both dividends and new share issues, so that $\lambda^{D}=\lambda^{N}=0$. In this case the first-order conditions simplify to

$$
\Pi_{I}=(1+r)
$$

and

$$
\Pi_{N}=(1+r)\left(\frac{1}{\gamma}-(1-f)\right)
$$

Notice that this requires $\left(\frac{1}{\gamma}-(1-f)\right) \geq 0$, or the standard 'pecking order' in which external finance is not less expensive than internal finance. This is satisfied automatically if $\gamma<1$, so that dividends are taxed more heavily than capital gains, but 
otherwise requires transactions costs to be high enough to outweigh the tax advantage of dividends. However firms facing a tax (or tax plus transaction cost) disadvantage of paying dividends do not reduce new share issues to zero here, because exposure to the external capital market is assumed to result in better corporate control.

In general, the levels of investment and new share issues are jointly determined by the interest rate $(r)$, the tax discrimination parameter $(\gamma)$ and the transaction cost $(f)$. An increase in dividend taxation implies a reduction in $\gamma$. Provided we remain at an internal solution, the first-order condition for new share issues (6) shows that this requires an increase in the marginal benefit of issuing new shares $\left(\Pi_{N}\right)$, which in turn requires a reduction in the level of new shares issued. In turn, a lower level of new equity will reduce the marginal productivity of investment $\left(\Pi_{I}\right)$ if the cross-derivative $\Pi_{I N}$ is strictly positive, thus implying a lower level of investment from (5). This is one channel through which higher dividend taxes can affect investment in this model. A higher level of dividend taxes will also result in a lower level of dividends, provided the reduction in investment is less than the reduction in new share issues.

The model also has a corner solution in which dividend payments are zero. This occurs when the inherited cash flow $(C)$ is so low relative to investment opportunities that, if the firm issues the optimal level of new shares $\left(N^{*}\right)$ suggested by the analysis above, it cannot finance the optimal level of investment $\left(I^{*}\right)$ and pay positive dividends in the current period. This results in a corner solution with $N>0$ so that $\lambda^{N}=0$, but with $D=0$ so that $\lambda^{D}>0$. In this case the first-order conditions are

$$
\Pi_{I}=(1+r)\left(1+\frac{\lambda^{D}}{\gamma}\right)
$$

and

$$
\Pi_{N}=(1+r)\left(\frac{1}{\gamma}-(1-f)\left(1+\frac{\lambda^{D}}{\gamma}\right)\right)
$$

Since $\lambda^{D}>0$, this requires $\Pi_{N}$ to be lower and $\Pi_{I}$ to be higher than they would be (for the same values of $r, \gamma$ and $f$ ) in the internal solution. Assuming that the own-partial derivatives dominate the cross-partial derivative, this implies that new share issues will be higher, and investment will be lower, than they would be if the 
same firm had inherited a level of cash flow that was high enough, given its investment opportunities, to enable it to pay strictly positive dividends.

We note that the firm is 'financially constrained' in this regime. A windfall increase in cash flow $(C)$ would reduce the shadow value of internal funds $\left(\lambda^{D}\right)$, reducing new share issues and increasing investment. Thus 'control benefits' of issuing new equity can rationalise why many firms simultaneously pay dividends and issue new shares (in the internal solution) ${ }^{34}$ without ruling out the possibility of some firms being subject to financial constraints. However the firms in this constrained regime are identified by having strictly zero dividends. ${ }^{35}$

The presence of this constrained regime provides a second channel through which dividend taxes can affect investment. As we noted above, for firms at an internal solution, a higher level of dividend taxes will tend to reduce both new share issues and investment. Assuming that the reduction in new issues exceeds the reduction in investment (i.e. that a higher level of dividend taxes results in lower dividends), this may shift a previously dividend-paying firm into the constrained regime. In this case the required return on investment increases from $(1+r)$ as in $(5)$ to the higher value in (7), and the chosen level of investment is lower.

A higher level of dividend taxation also reduces investment for firms that are within the constrained regime. To illustrate this, suppose that the marginal benefit $\Pi_{N}$ falls to zero beyond some level of new issues. In this case, the first-order condition for new issues (8) gives

$$
\left(1+\frac{\lambda^{D}}{\gamma}\right)=\frac{1}{\gamma(1-f)}>1
$$

and the first-order condition for investment becomes

$$
\Pi_{I}=\frac{1+r}{\gamma(1-f)}>1+r
$$

\footnotetext{
${ }^{34}$ In the sample of quoted non-financial UK companies that we analyse in section 4, dividends are paid in $96 \%$ of the accounting periods in which firms issue new shares.

${ }^{35}$ As noted by Hayashi (1985) and emphasised by Fazzari, Hubbard and Petersen (1988), investment also displays 'excess sensitivity' to cash flow in a constrained regime of the standard new view or pecking order model. See Bond and Cummins (2001) and Bond et al. (2004) for recent evidence on investment-cash flow sensitivity in samples of quoted US and UK companies.
} 
In this limiting case, the required rate of return on investment is increasing in dividend taxes, which lower the valuation parameter $\gamma$. This corresponds to the standard result in the 'new view' model that dividend taxes raise the cost of capital for firms that pay zero dividends and whose marginal source of finance is new equity. ${ }^{36}$

The general model is illustrated in Figure 4. A firm with inherited cash flow $C$ chooses to issue new shares $N^{*}$ from (6) provided it is at an internal solution for dividends. A firm with investment opportunities described by the marginal profitability schedule $\Pi_{I}^{A}$ chooses to invest $I^{*}$ and pays dividends $\left(C+(1-f) N^{*}-I^{*}\right)$. An otherwise similar firm with more attractive investment opportunities described by the schedule $\Pi_{I}^{B}$ would be at a corner solution with zero dividends. ${ }^{37}$ This firm invests $I^{B}$ and issues new shares to the value $\frac{I^{B}-C}{1-f}$.

Figure 5 illustrates the effects of an increase in dividend taxation for a firm that remains within the dividend-paying regime. The optimal level of new shares falls from $N_{0}^{*}$ to $N_{1}^{*}$ and the optimal level of investment falls from $I_{0}^{*}$ to $I_{1}^{*}$. Dividend payments fall by the amount $(1-f)\left(N_{0}^{*}-N_{1}^{*}\right)-\left(I_{0}^{*}-I_{1}^{*}\right)$. Notice that the cost of capital does not depend on the level of dividend taxation in this regime, but investment may nevertheless fall if the more limited use of finance from the external capital market reduces the marginal profitability of investment.

Figure 6 illustrates the effects for a firm that shifts from the dividend-paying regime to the zero dividend regime. This results from the reduction in $N^{*}$. In this case the cost of capital is affected, and investment falls even if the marginal profitability of investment does not depend on the level of new share issues. Investment falls for two reasons in the general case illustrated. Dividends obviously fall to zero for firms in this position.

Figure 7 illustrates the effects for a firm that remains within the zero dividends

\footnotetext{
${ }^{36}$ Strictly this holds when at least part of the return on the investment will be paid out in the form of dividends. In this case higher dividend taxes reduce the return on the investment to shareholders, with no corresponding reduction in the cost borne by shareholders when the investment is financed by new equity.

${ }^{37}$ In Figure 1 we assume for simplicity that these two firms would have the same level of new issues $N^{*}$ in the unconstrained regime.
} 
regime. For such firms the cost of capital increases, and investment falls, whether or not marginal profitability depends on new share issues. Clearly dividends are unchanged in this case.

A special case of the model that is of some interest is the case where $\Pi_{I N}=0$, so that the payoff is additively separable in the levels of investment and new share issues. In this case, for firms at an internal solution, the first-order condition (5) determines investment and the first-order condition (6) determines new issues. Firms may simultaneously issue new shares and pay dividends, and dividend taxation will influence the level of dividends, but - as in the standard 'new view' - investment does not depend on the level of dividend taxation for firms that pay positive dividends. There is still a corner solution with zero dividends, and an increase in the level of dividend taxes reduces investment for firms that are in (or sufficiently close to) this regime.

Another special case of the model has $\Pi_{N}=\Pi_{N N}=\Pi_{I N}=0$. In this case we have a version of the standard 'new view' model, with transactions costs for new equity issues incorporated to ensure that retained earnings remain the preferred source of finance even if the relevant shareholder has a tax preference for dividend income over capital gains. Firms should not simultaneously pay dividends and issue new shares, and an increase in the level of dividend taxation has no effect on either dividends or investment for dividend-paying firms.

Finally the Modigliani-Miller separation between real and financial decisions emerges in the special case with $\Pi_{N}=\Pi_{N N}=\Pi_{I N}=0, \gamma=1$ and $f=0 .{ }^{38}$ In this case investment is determined by the first-order condition (5) for all firms, and financial policy is indeterminate.

To summarise, the key prediction of our general model is that an increase in dividend taxation for relevant shareholders will reduce dividend payments for dividendpaying firms, if the higher tax-cost of paying dividends induces firms to reduce their reliance on new share issues. This may also reduce investment for these firms, if the

\footnotetext{
${ }^{38}$ Or, more generally, with $\gamma^{-1}=1-f$.
} 
more limited use of finance from the external capital market reduces the marginal profitability of investment.

\section{A dividend tax paid by firms}

We now extend this model to include a tax on dividends paid by the firm. This provides a stylised representation of the tax cost associated with unrelieved Advance Corporation Tax in the UK, and in particular allows us to consider the implications for dividends of the corporate tax saving achieved by firms that switched from paying ordinary dividends to paying Foreign Income Dividemds.

If the firm pays tax $T$ on its dividend payments, the full cost of paying a cash dividend $D$ to its shareholders becomes $D^{F}=D+T$. If this tax is expressed as a rate $s$ charged on $D^{F}$, we obtain $D^{F}=D+s D^{F}=D /(1-s)$. The firm thus pays a dividend of $D=(1-s)(C-I+(1-f) N) \geq 0$ in the first period, and $(1-s) \Pi$ in the second period. The firm now maximises

$$
\begin{aligned}
V= & \gamma(1-s)(C-I+(1-f) N)-N+\lambda^{D}(1-s)(C-I+(1-f) N)+\lambda^{N} N \\
& +\gamma(1-s) \beta \Pi(I, N) .
\end{aligned}
$$

In general, the first-order condition for investment is still given by equation (3) above, whilst the first-order condition for new issues becomes

$$
\lambda^{D}(1-s)(1-f)+\lambda^{N}=1-\gamma(1-s)(1-f)-\gamma(1-s) \beta \Pi_{N} .
$$

For dividend-paying firms, we obtain

$$
\Pi_{N}=(1+r)\left(\frac{1}{\gamma(1-s)}-(1-f)\right) .
$$

If the optimal level of new share issues does not depend on the level of dividend taxation, we obtain the 'new view' result that, for dividend-paying firms, a reduction in the rate of a dividend tax $(s)$ levied on firms will leave investment and hence the full cost of paying dividends $\left(D^{F}\right)$ unchanged. In this case the cash dividend $(D)$ 
paid to shareholders increases, to keep $D^{F}=D /(1-s)$ constant. The tax saved by the firm is simply paid out to its shareholders. If this reduction in dividend taxation induces the firm to increase the level of new issues, this will imply a further increase in both $D^{F}$ and $D$, and if $\Pi_{I N}>0$ could also result in an increase in investment. 
Table 1. Tax treatment of ordinary dividends and Foreign Income Dividends

\begin{tabular}{l|c|c} 
& \multicolumn{2}{|c}{ Type of shareholder } \\
\hline Before July 1997 & UK pension fund & UK basic rate taxpayer \\
\hline Ordinary dividend & $1.25-0.25 \alpha$ & $1-0.25 \alpha$ \\
Foreign Income Dividend & $1-\beta$ & $1-\beta$ \\
\hline After July 1997 & $1-0.25 \alpha$ & $1-0.25 \alpha$ \\
\hline Ordinary dividend & $1-\beta$ & $1-\beta$
\end{tabular}

Entries show the dividend received if the firm issues $£ 1$ of new equity and pays out the proceeds immediately as either an ordinary dividend or a Foreign Income Dividend, to either a UK pension fund or a UK basic rate taxpayer.

$0 \leq \alpha \leq 1$ reflects the tax cost of surplus Advance Corporation Tax, with $\alpha=0$ indicating no surplus ACT and $\alpha=1$ indicating extreme irrecoverable ACT.

$\beta \geq 0$ reflects the tax cost of repatriating foreign profits in order to pay a Foreign Income Dividend. 
Table 2. UK firms paying Foreign Income Dividends

\begin{tabular}{l|ccc} 
Year & $\begin{array}{c}\text { Number } \\
\text { of firms }\end{array}$ & $\begin{array}{c}\text { Proportion of firms } \\
\text { that paid dividends } \\
(\%)\end{array}$ & $\begin{array}{l}\text { Proportion of firms } \\
\text { with foreign activities } \\
\text { that paid dividends (\%) }\end{array}$ \\
\hline July 94 - June 95 & 5 & 0.4 & 0.6 \\
July 95 - June 96 & 33 & 2.4 & 3.8 \\
July 96 - June 97 & 46 & 3.2 & 5.1 \\
\hline July 97 - June 98 & 130 & 8.9 & 14.5 \\
July 98 - March 99 & 108 & 8.2 & 13.4
\end{tabular}

Notes.

Based on a sample of 1,788 quoted UK companies.

Presence of foreign activities is inferred from reported payment of foreign corporate taxes.

Data from Thomson Financial Datastream. 
Table 3. Descriptive statistics

\begin{tabular}{l|rrr} 
& \multicolumn{1}{|c}{ Mean } & $\begin{array}{r}\text { Standard } \\
\text { deviation }\end{array}$ & \multicolumn{1}{c}{ Median } \\
FIDswitch firms & & & \\
& & & \\
Dividends & 68,132 & 172,180 & 26,899 \\
Profits & 123,480 & 257,309 & 51,500 \\
Sales & $2,281,408$ & $5,558,159$ & $1,048,100$ \\
Investment & 109,128 & 175,311 & 40,870 \\
& & & \\
NeverFID firms & & & \\
& & & \\
Dividends & 32,261 & 216,987 & 2,685 \\
Profits & 41,589 & 157,930 & 5,997 \\
Sales & 756,946 & $1,943,478$ & 120,622 \\
Investment & 47,912 & 195,194 & 4,794 \\
& & & \\
Other firms & & & \\
& & & \\
Dividends & 11,004 & 57,625 & 956 \\
Profits & 29,280 & 200,095 & 2,245 \\
Sales & 396,658 & $2,077,500$ & 56,729 \\
Investment & 28,458 & 149,267 & 2,102 \\
& & & \\
All firms & & & \\
& & & \\
Dividends & 24,453 & 152,977 & 1,897 \\
Profits & 42,110 & 191,328 & 4,040 \\
Sales & 702,977 & $2,566,452$ & 98,755 \\
Investment & 43,258 & 172,662 & 3,546 \\
& & &
\end{tabular}

Notes.

Sample of 690 firms in 1997. 59 of these are classified to the FIDswitch group, and 278 are classified to the NeverFID group.

All figures in thousands of UK pounds. 
Table 4. Dividend models

Dependent variable: Total dividends $\left(\operatorname{Div}_{i t}\right)$

\begin{tabular}{|c|c|c|c|c|}
\hline $\begin{array}{l}\text { Firm } \\
\text { fixed effects }\end{array}$ & $\begin{array}{l}\text { (i) } \\
\text { No }\end{array}$ & $\begin{array}{l}\text { (ii) } \\
\text { Yes }\end{array}$ & $\begin{array}{l}\text { (iii) } \\
\text { No }\end{array}$ & $\begin{array}{l}\text { (iv) } \\
\text { Yes }\end{array}$ \\
\hline Sales $_{\text {it }}$ & $\begin{array}{l}0.017 \\
(0.002) * * *\end{array}$ & $\begin{array}{l}0.020 \\
(0.002) * * *\end{array}$ & $\begin{array}{l}0.016 \\
(0.001)^{* * *}\end{array}$ & $\begin{array}{l}0.018 \\
(0.002) * * *\end{array}$ \\
\hline Profits $_{i t}$ & $\begin{array}{l}0.149 \\
(0.024) * * *\end{array}$ & $\begin{array}{l}0.045 \\
(0.017) * * *\end{array}$ & $\begin{array}{l}0.116 \\
(0.017) * * *\end{array}$ & $\begin{array}{l}0.047 \\
(0.016)^{* * *}\end{array}$ \\
\hline $\begin{array}{l}\text { Lagged } \\
\text { profits }_{\text {it }}\end{array}$ & & & $\begin{array}{l}0.080 \\
(0.012) * * *\end{array}$ & $\begin{array}{l}0.024 \\
(0.006)^{* * *}\end{array}$ \\
\hline FIDswitch $_{i}$ & $\begin{array}{l}-379.199 \\
(393.205)\end{array}$ & & $\begin{array}{l}-67.651 \\
(379.640)\end{array}$ & \\
\hline NeverFID $_{i}$ & $\begin{array}{l}14.362 \\
(42.143)\end{array}$ & & $\begin{array}{l}46.525 \\
(54.635)\end{array}$ & \\
\hline Post97 & $\begin{array}{l}40.015 \\
(22.818)^{*}\end{array}$ & $\begin{array}{l}-5.687 \\
(8.729)\end{array}$ & $\begin{array}{l}25.407 \\
(18.215)\end{array}$ & $\begin{array}{l}-6.578 \\
(8.100)\end{array}$ \\
\hline $\begin{array}{l}\text { Post97 }_{\mathrm{t}}^{*} \\
\text { FIDswitch }_{\mathrm{i}}\end{array}$ & $\begin{array}{l}866.821 \\
(390.297)^{* *}\end{array}$ & $\begin{array}{l}727.184 \\
(324.477)^{* *}\end{array}$ & $\begin{array}{l}613.339 \\
(342.275)^{*}\end{array}$ & $\begin{array}{l}682.462 \\
(290.172)^{* *}\end{array}$ \\
\hline $\begin{array}{l}\text { Post97 } * \\
\text { NeverFID }_{\mathrm{i}}\end{array}$ & $\begin{array}{l}-104.404 \\
(61.157)^{*}\end{array}$ & $\begin{array}{l}6.075 \\
(27.762)\end{array}$ & $\begin{array}{l}-103.041 \\
(66.695)\end{array}$ & $\begin{array}{l}-8.819 \\
(36.134)\end{array}$ \\
\hline Constant & $\begin{array}{l}31.324 \\
(24.218)\end{array}$ & $\begin{array}{l}66.743 \\
(5.629) * * *\end{array}$ & $\begin{array}{l}32.300 \\
(20.027)\end{array}$ & $\begin{array}{l}67.044 \\
(5.441)^{* * *}\end{array}$ \\
\hline $\begin{array}{l}\text { Observations } \\
\text { R-squared }\end{array}$ & $\begin{array}{l}4219 \\
0.57\end{array}$ & $\begin{array}{l}4219 \\
0.87\end{array}$ & $\begin{array}{l}4219 \\
0.63\end{array}$ & $\begin{array}{l}4219 \\
0.88\end{array}$ \\
\hline
\end{tabular}

Robust standard errors in parentheses

$*$ significant at $10 \%$; * significant at $5 \%$; *** significant at $1 \%$ 
Table 5. Investment models

Dependent variable: Investment rate $(\mathrm{I} / \mathrm{K})_{\text {it }}$

\begin{tabular}{|c|c|c|c|c|}
\hline $\begin{array}{l}\text { Firm } \\
\text { fixed effects }\end{array}$ & $\begin{array}{l}\text { (i) } \\
\text { No }\end{array}$ & $\begin{array}{l}\text { (ii) } \\
\text { Yes }\end{array}$ & $\begin{array}{l}\text { (iii) } \\
\text { No }\end{array}$ & $\begin{array}{l}\text { (iv) } \\
\text { Yes }\end{array}$ \\
\hline $\begin{array}{l}\text { Real sales } \\
\text { growth }_{\text {it }}\end{array}$ & $\begin{array}{l}0.391 \\
(0.036)^{* * *}\end{array}$ & $\begin{array}{l}0.317 \\
(0.042)^{* * *}\end{array}$ & $\begin{array}{l}0.382 \\
(0.038)^{* * *}\end{array}$ & $\begin{array}{l}0.303 \\
(0.045)^{* * *}\end{array}$ \\
\hline $\begin{array}{l}\text { Lagged real } \\
\text { sales growth }\end{array}$ & $\begin{array}{l}0.066 \\
(0.029)^{* *}\end{array}$ & $\begin{array}{l}0.002 \\
(0.035)\end{array}$ & $\begin{array}{l}0.058 \\
(0.027)^{* *}\end{array}$ & $\begin{array}{l}-0.011 \\
(0.033)\end{array}$ \\
\hline Profitability $_{i t}$ & & & $\begin{array}{l}0.026 \\
(0.045)\end{array}$ & $\begin{array}{l}0.040 \\
(0.064)\end{array}$ \\
\hline $\begin{array}{l}\text { Lagged } \\
\text { profitability }{ }_{i t}\end{array}$ & & & $\begin{array}{l}0.125 \\
(0.070)^{*}\end{array}$ & $\begin{array}{l}0.167 \\
(0.085)^{* *}\end{array}$ \\
\hline FIDswitch $_{\mathrm{i}}$ & $\begin{array}{l}0.000 \\
(0.051)\end{array}$ & & $\begin{array}{l}0.001 \\
(0.051)\end{array}$ & \\
\hline NeverFID $_{i}$ & $\begin{array}{l}-0.003 \\
(0.020)\end{array}$ & & $\begin{array}{l}-0.003 \\
(0.020)\end{array}$ & \\
\hline Post $97_{t}$ & $\begin{array}{l}-0.029 \\
(0.017)^{*}\end{array}$ & $\begin{array}{l}-0.032 \\
(0.019)^{*}\end{array}$ & $\begin{array}{l}-0.031 \\
(0.017)^{*}\end{array}$ & $\begin{array}{l}-0.033 \\
(0.018)^{*}\end{array}$ \\
\hline $\begin{array}{l}\text { Post97 } * \\
\text { FIDswitch }_{\mathrm{i}}\end{array}$ & $\begin{array}{l}0.013 \\
(0.055)\end{array}$ & $\begin{array}{l}0.010 \\
(0.062)\end{array}$ & $\begin{array}{l}0.012 \\
(0.055)\end{array}$ & $\begin{array}{l}0.007 \\
(0.061)\end{array}$ \\
\hline $\begin{array}{l}\text { Post97 }{ }_{t}^{*} \\
\text { NeverFID }_{i}\end{array}$ & $\begin{array}{l}0.016 \\
(0.021)\end{array}$ & $\begin{array}{l}0.007 \\
(0.024)\end{array}$ & $\begin{array}{l}0.017 \\
(0.021)\end{array}$ & $\begin{array}{l}0.006 \\
(0.024)\end{array}$ \\
\hline Constant & $\begin{array}{l}0.170 \\
(0.017)^{* * *}\end{array}$ & $\begin{array}{l}0.180 \\
(0.008)^{* * *}\end{array}$ & $\begin{array}{l}0.164 \\
(0.018)^{* * *}\end{array}$ & $\begin{array}{l}0.173 \\
(0.010)^{* * *}\end{array}$ \\
\hline $\begin{array}{l}\text { Observations } \\
\text { R-squared }\end{array}$ & $\begin{array}{l}3988 \\
0.08\end{array}$ & $\begin{array}{l}3988 \\
0.31\end{array}$ & $\begin{array}{l}3988 \\
0.08\end{array}$ & $\begin{array}{l}3988 \\
0.32\end{array}$ \\
\hline
\end{tabular}

Robust standard errors in parentheses

$*$ significant at $10 \% ; * *$ significant at $5 \% ; * * *$ significant at $1 \%$ 


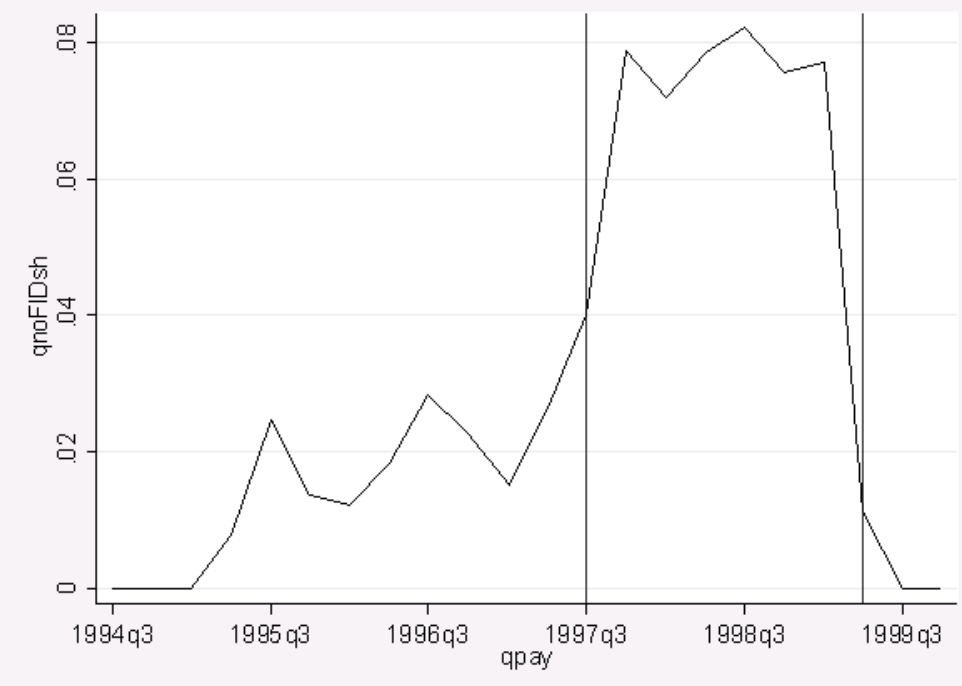

Figure 1: Number of FIDs relative to number of dividend payments 


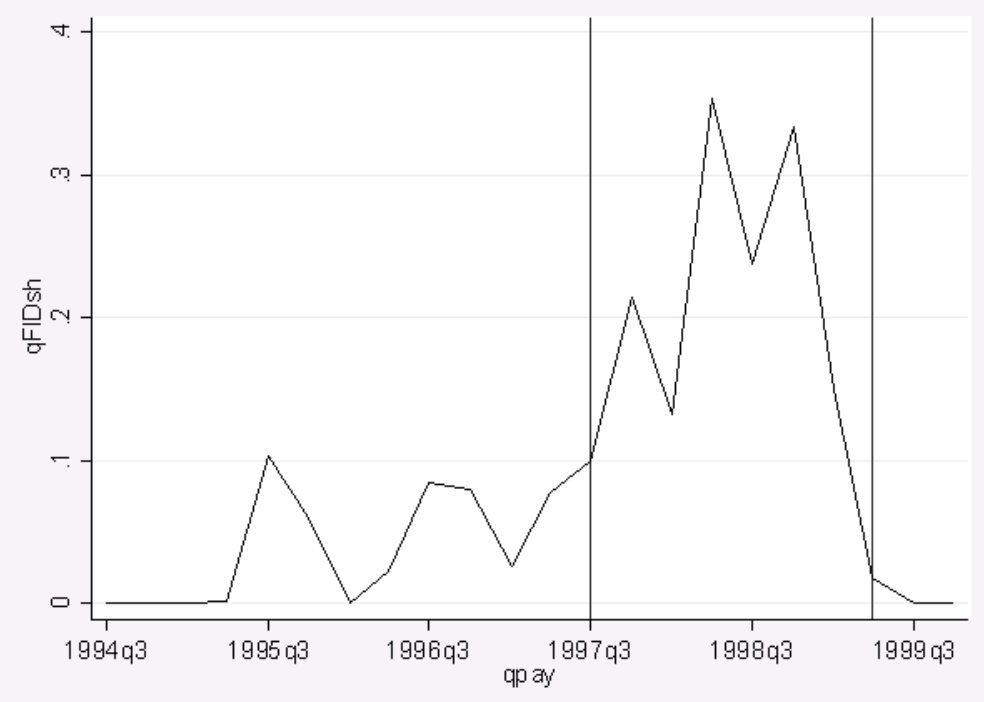

Figure 2: Value of FIDs relative to value of all dividend payments 


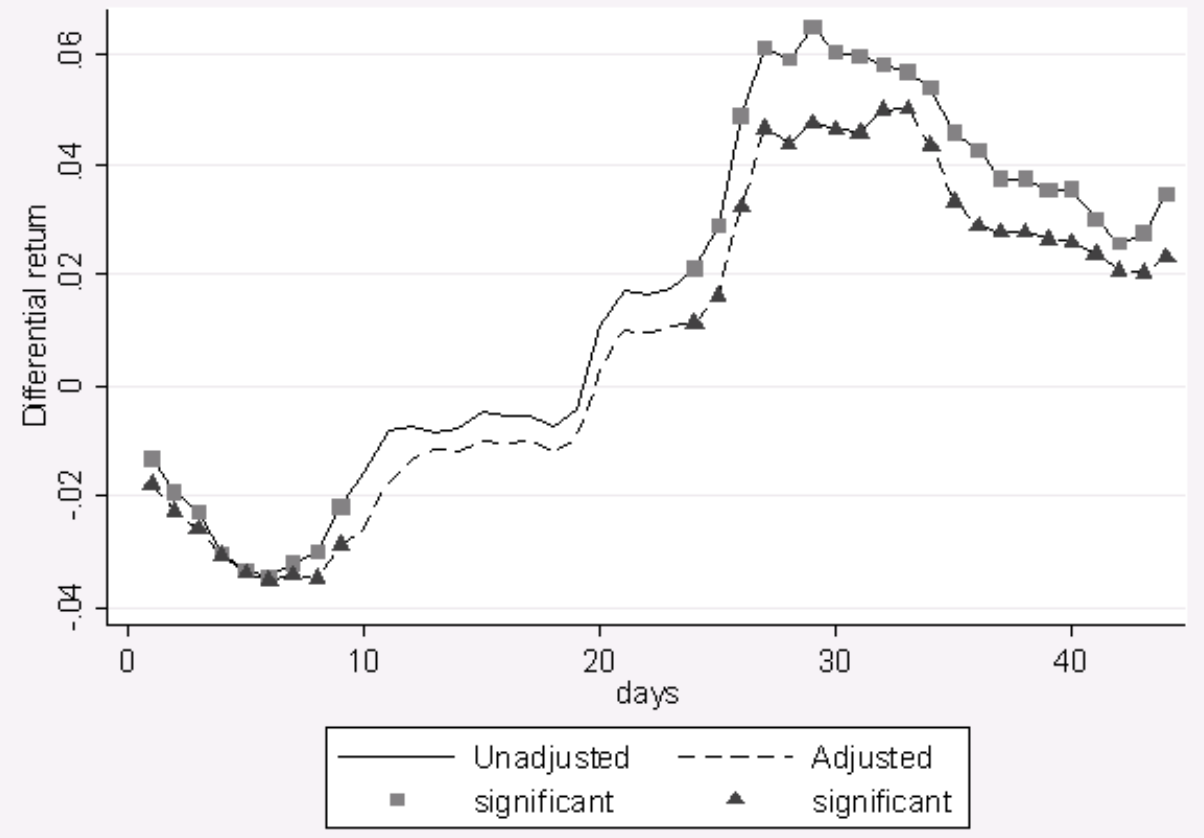

Figure 3: Difference in cumulative returns 


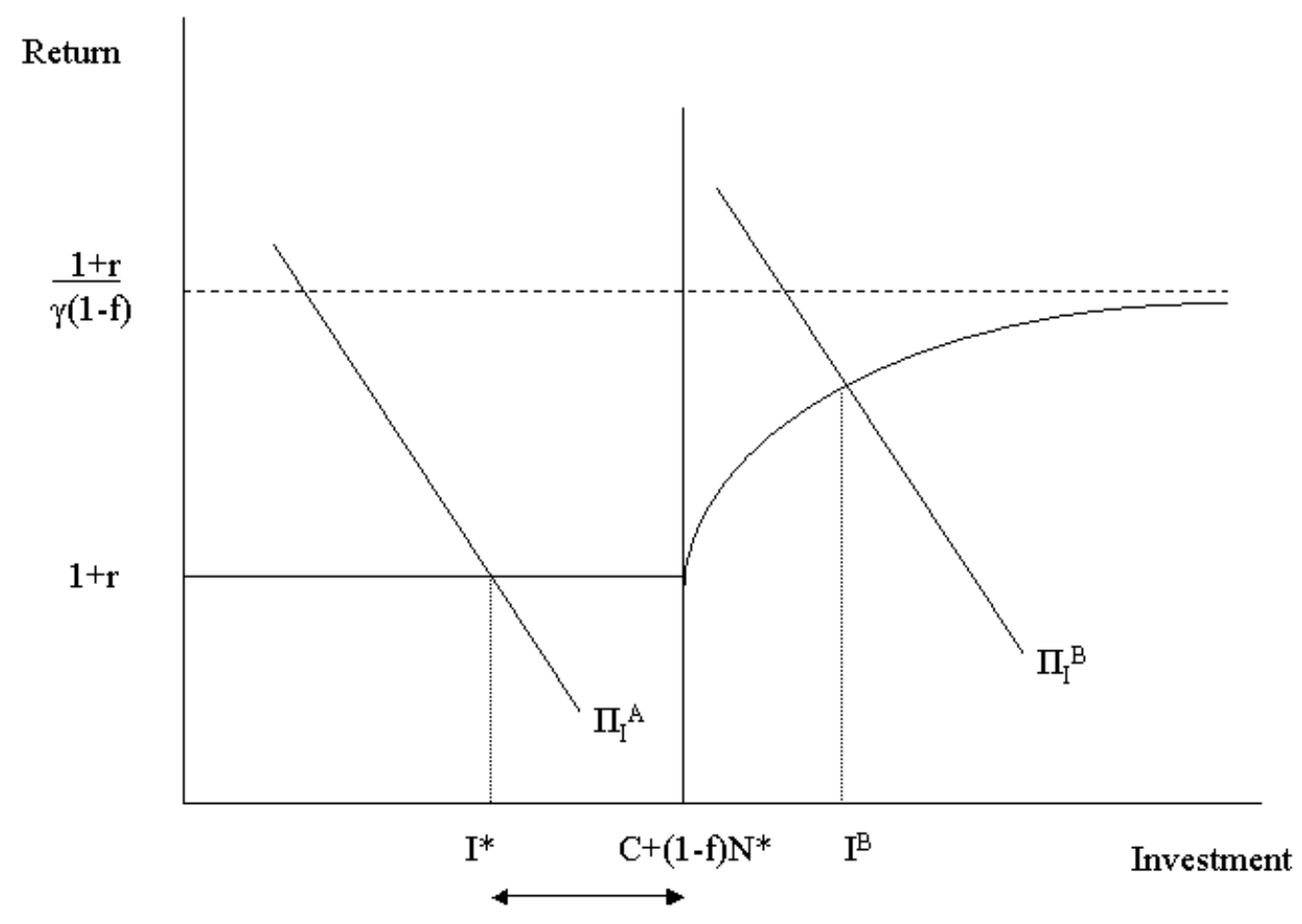

Figure 4: Dividends and investment 


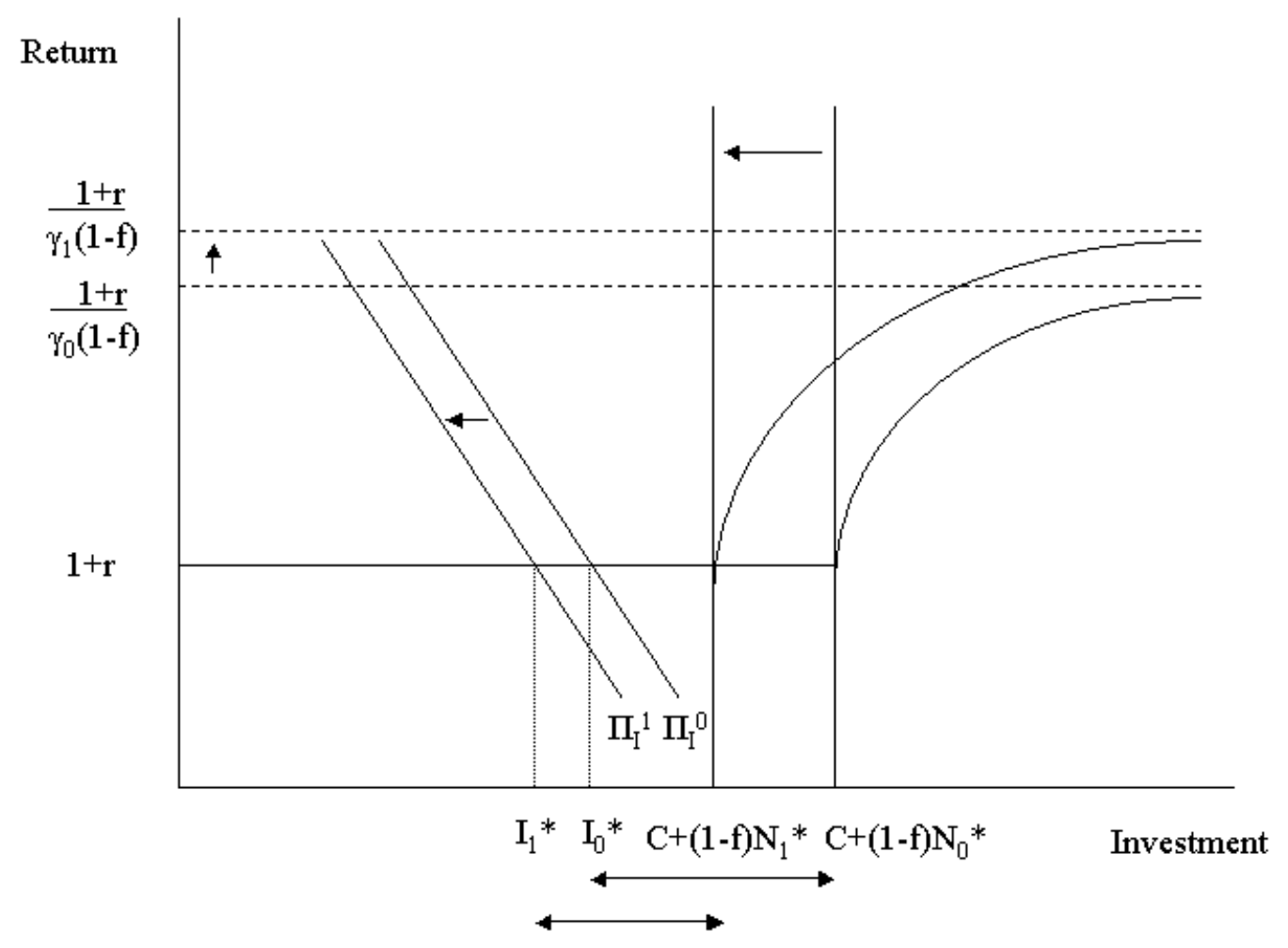

Figure 5: Higher dividend taxes; dividend paying firms 


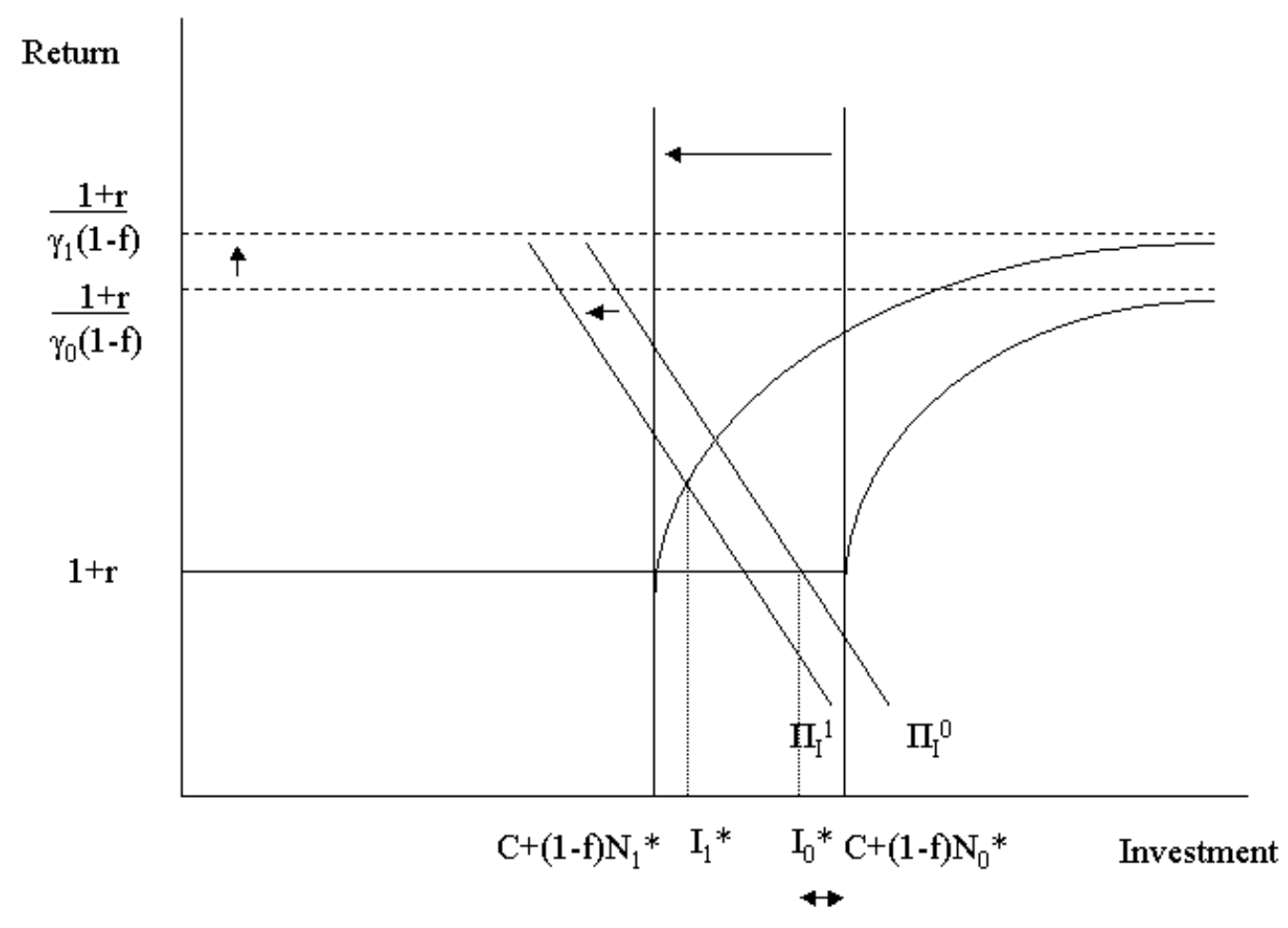

Figure 6: Higher dividend taxes; regime switching firms 


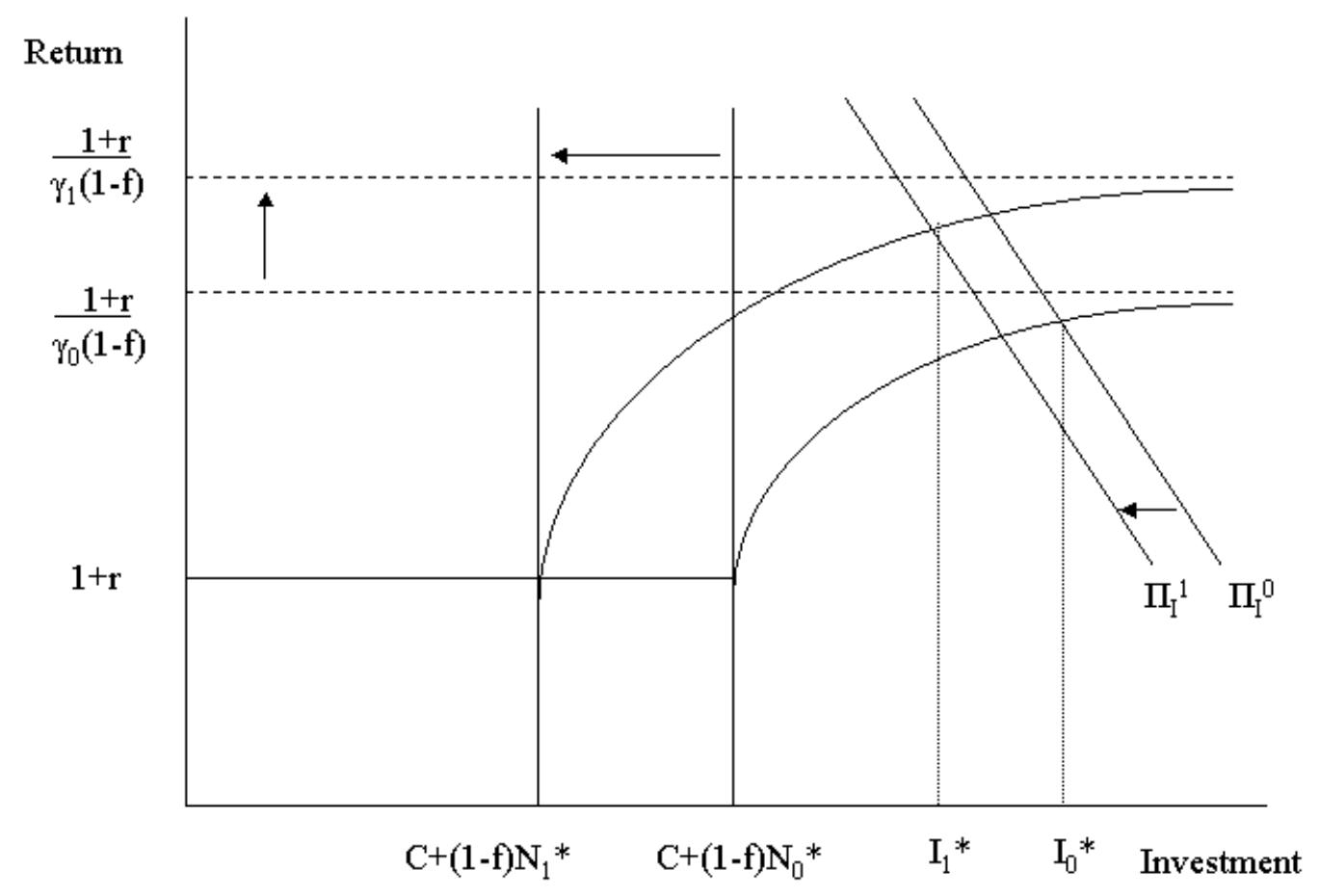

Figure 7: Higher dividend taxes; zero dividend firms 